\title{
TanDEM-X PolarDEM 90m of Antarctica: Generation and error characterization
}

\author{
Wessel Birgit ${ }^{1}$, Huber Martin ${ }^{1}$, Wohlfart Christian ${ }^{1,3}$, Bertram Adina ${ }^{1}$, Osterkamp Nicole ${ }^{2}$, \\ Marschalk Ursula $^{1}$, Gruber Astrid ${ }^{1,4}$, Reuß Felix ${ }^{2,5}$, Abdullahi Sahra ${ }^{1}$, Georg Isabel ${ }^{2}$, and Roth Achim ${ }^{1}$ \\ ${ }^{1}$ German Remote Sensing Data Center, German Aerospace Center, Oberpfaffenhofen, 82234 Weßling, Germany \\ ${ }^{2}$ Company for Remote Sensing and Environmental Research (SLU), Kohlsteiner Str. 5, 81243 München, Germany \\ ${ }^{3}$ Roche Diagnostics GmbH, Data Office, Nonnenwald 2, 82377 Penzberg, Germany \\ ${ }^{4}$ Stemmer Imaging, Gutenbergstr. 9-13, 82178 Puchheim, Germany \\ ${ }^{5}$ Department of Geodesy and Geoinformation, TU Wien, 1040 Vienna, Austria
}

Correspondence: Birgit Wessel (Birgit.Wessel@dlr.de)

\begin{abstract}
We present the generation and validation of an updated version of the TanDEM-X Digital Elevation Model (DEM) of Antarctica: the TanDEM-X PolarDEM 90m of Antarctica. Improvements compared to the global TanDEM-X DEM version include filling of gaps with newer acquisitions, interpolating of smaller voids, smoothing of noisy areas and replacing frozen or open sea areas with geoid undulations. For the latter, a new semi-automatic editing approach allowed the delineation of the coastline from DEM and amplitude data. Finally, the DEM was transformed into the cartographic Antarctic Polar Stereographic projection with a homogeneous metric spacing in northing and easting of 90 meters. As X-Band synthetic aperture radar (SAR) penetrates the snow and ice pack by several meters a new concept for absolute height adjustment was set up that relies on areas with stable penetration conditions and on ICESat (Ice, Cloud, and land Elevation Satellite) elevations. After DEM generation and editing, a sophisticated height error characterization of the whole Antarctic continent with ICESat and IceBridge data was carried out and a validation over blue ice achieved a mean vertical height error of just $-0.3 \mathrm{~m} \pm 2.5 \mathrm{~m}$ standard deviation. The filled and edited Antarctic TanDEM-X PolarDEM 90m is outstanding due to its accuracy, homogeneity and coverage completeness. It is freely available for scientific purposes and provides a high-resolution data set as basis for polar research, such as ice velocity, mass balance estimation or ortho-rectification.
\end{abstract}

\section{Introduction}

The Antarctic continent is almost entirely covered by a vast ice sheet of approximately 27 million cubic kilometres. This ice sheet plays an important role in terms of climate change and rising temperatures worldwide, not least because it holds water that would raise the global sea level by $58 \mathrm{~m}$ (Fretwell et al., 2013; Shepherd et al., 2018). Digital Elevation Models (DEMs) provide crucial information about the ice sheet topography for monitoring and modelling ice sheet dynamics, glacier velocities and mass balance analyses, in order to understand these processes and their potential contribution to global sea level rise (Sutterley et al., 2014; Forsberg et al., 2017; Mengel et al., 2018). Recently, the long term standard reference BEDMAP2 DEM (Fretwell et al., 2013) has been replaced by several up-to-date DEM products for Antarctica based on various remote sensing 
data including radar altimetry, optical data or laser altimetry. These include the very high resolution $(8 \mathrm{~m})$ Reference Elevation Model of Antarctica (REMA) (Howat et al., 2019, 2018) which is created from stereo-photogrammetry using DigitalGlobe satellite imagery (mostly from the 2015 and 2016 austral summer seasons), or CryoSat-2 DEMs based on 2010 to 2016 data with a spatial resolution of $1 \mathrm{~km}$ (Helm et al., 2014; Slater et al., 2018).

The German TanDEM-X (TerraSAR-X add-on for Digital Elevation Measurements) mission was the first spaceborne interferometric Synthetic Aperture Radar (InSAR) mission in bistatic mode (Krieger et al., 2007), which mapped the entire Antarctic ice sheet and its complex marginal areas between 2013 and 2014 (Borla Tridon et al., 2013). TanDEM-X is comprised of two almost identical satellites, TerraSAR-X and TanDEM-X, performing X-Band InSAR acquisitions in bistatic configuration, where one satellite transmits and both simultaneously receive the backscattered signal. This enables the generation of highly accurate interferograms, which do not suffer from temporal and atmospheric decorrelation. In 2016, full global TanDEM-X DEM coverage at $12 \mathrm{~m}$ spatial resolution ( 0.4 arcsecond) was completed. For the cryosphere, it provides an up-to-date high-resolution elevation of glaciers and ice sheets in high latitudes.

However, interferometric elevation data suffer from penetration of the X-Band SAR signal into the snow and ice surface by several meters (Rott et al., 2021; Fischer et al., 2020; Dehecq et al., 2016; Wessel et al., 2016) and therefore complicate calibration as well as validation and comparison to other data. Further, the TanDEM-X DEM is an unedited elevation model with erroneous data such as invalid data on water areas, noise or even holes, all of which hinder further usage. In this paper, we detail the special adaptations made for generating the TanDEM-X DEM for Antarctica: a new block adjustment strategy for InSAR DEMs over larger ice sheets and a meticulous mosaicking of individual DEM scenes. Furtheron, we filled gaps in the TanDEM-X DEM (which uses data from 2013-2014) with newer acquisitions taken between July 2016 and September 2017 and re-edited the coastlines. To identify water areas and assign homogeneous height values, we developed a semi-automatic approach for coastline delineation. This updated and resampled version is called TanDEM-X PolarDEM for Antarctica and is now available in $90 \mathrm{~m}$ Polar Stereographic projection for scientific use (https://geoservice.dlr.de/web/maps/tdm:polardem90: antarctica, last access: 21 December 2020). The absolute vertical accuracy is characterized in this paper by an evaluation against ICESat and Icebridge data depending on ice classes. Notably, blue ice areas (BIAs) are used to validate the absolute accuracy of this new InSAR DEM of Antarctica. BIAs are a phenomenon unique to Antarctica, describing very dense and snow-free ice areas (Bintanja, 1999). The high density of BIAs prevents the X-Band SAR signal from penetrating into the ice (Rott et al., 2017) which is of significance for this study since InSAR measurements over BIAs consequently represent the same elevations as laser heights.

\section{Data}

\subsection{TanDEM-X data}

Input to the TanDEM-X DEM product (Wessel, 2018) of Antarctica were two complete coverages acquired with bistatic interferometric SAR and with different baselines. All acquisitions were taken in austral winter to avoid the melting season along the coast to guarantee good coherence conditions (Rizzoli et al., 2017). The first coverage was taken between April and 


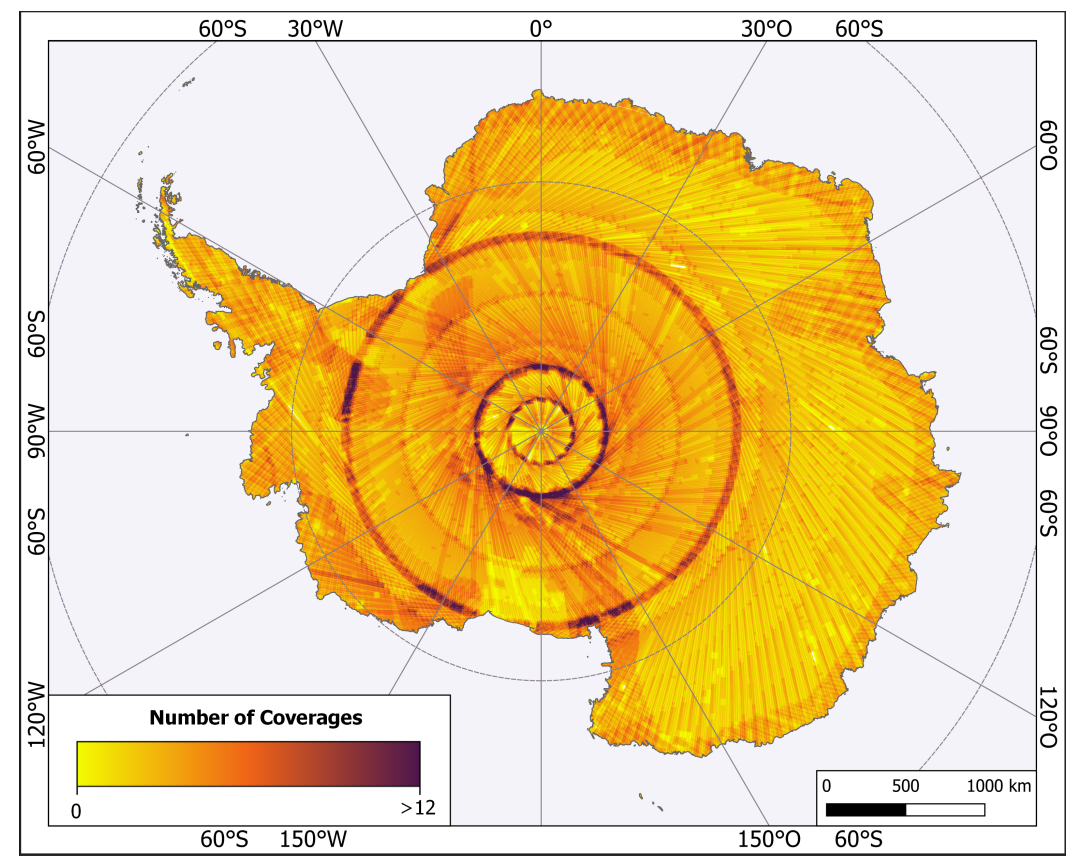

Figure 1. Number of coverages of TanDEM-X DEM data takes.

November 2013, the second between April and October 2014. In addition, for the mountainous areas, a third and a fourth coverage with larger heights of ambiguity from the opposite viewing geometry were performed in mid-2014 (Borla Tridon et al., 2013). For the inner part of Antarctica, left-looking mode had to be applied since the inclination of the TerraSAR-X and TanDEM-X satellite orbits inhibits the visibility of the South Pole from the nominal right-looking direction. For this, over a radius of $1,300 \mathrm{~km}$ from the South Pole, left-looking observations with shallower incidence angles (above $50^{\circ}$ ) were used (see Fig. 1). In total, with a time span of 1.5 years, a very compact temporal acquisition base could be accomplished with 4,151 data takes resulting in approx. 41,000 DEM scenes having a spatial resolution of approximately 10-12 m. After the finalization of the TanDEM-X DEM in 2016 still some smaller DEM gaps remained, i.e. void data which result from the absence of acquired data or input DEMs with satisfying quality. For these residual smaller gaps ranging from $2 \mathrm{~km}^{2}$ to $2,600 \mathrm{~km}^{2}$ a so-called DEM gap filling acquisition phase for Antarctica took place from July 2016 to September 2017.

\subsection{ICESat}

In 2003 the National Aeronautics and Space Administration (NASA) launched ICESat with the Geoscience Laser Altimeter System (GLAS) onboard. GLAS is a laser altimeter designed to measure ice-sheet topography with a footprint of about $70 \mathrm{~m}$ in diameter spaced at about $172 \mathrm{~m}$ along track while not penetrating into the snowpack (Brenner et al., 2007). It observed the ice sheets from 2003 to 2009. The specific data set used for supporting the TanDEM-X mission is the GLAS/ICESat L2 Global Land Surface Altimetry Data, Version 31, GLA14 (Zwally et al., 2012). 
To ensure a good height accuracy and to reduce slope induced elevation errors of ICESat points we used the classification information provided for each measurement point (Schutz et al., 2005) to select the most reliable points (Hueso Gonzalez et al., 2010). According to a previous accuracy study, the standard deviation for these selected GCPs should be below $2 \mathrm{~m}$ under optimal conditions (ICESat points on flat bare land) (Huber et al., 2009), another study for flat ice areas report a standard deviation even below $1 \mathrm{~m}$ (Brenner et al., 2007). For comparison, all elevation values of the TanDEM-X DEM within a single ICESat footprint were averaged according to a laser specific weighting function (Harding and Carabajal, 2005). The estimated Gaussian elevations of ICESat were used as heights and a coarse outlier detection was performed by sorting out extreme outliers that differ more than $100 \mathrm{~m}$ from the TanDEM-X elevations. The selected ICESat points are used as ground control points within the TanDEM-X DEM block adjustment and for validation. For validation points, the standard deviation of the TanDEM-X DEM scene within the footprint must be below $1 \mathrm{~m}$ and only the best 10 ICESat points per one $50 \mathrm{~km}$ long DEM scene were considered for the block adjustment.

For the absolute height accuracy evaluation, a well distribution of points over the whole continent is important. This was realized via a fixed number of points per geocell. The TanDEM-X product is partitioned into geocells, whose size is latitude dependent $\left(1^{\circ} \times 2^{\circ}\right.$ between $60^{\circ}$ and $80^{\circ}$ South, and $1^{\circ} \times 4^{\circ}$ between $80^{\circ}$ and $90^{\circ}$ South). In total 2,349 geocells were evaluated between latitudes of $60^{\circ}$ and $87^{\circ}$ South. Note that the geocell rows S88, S89, S90 do not contain any ICESat points because the polar cap could not be covered due to the ICESat orbit geometry. For each geocell only the most 1,000 reliable points were selected for validation. This reduces the original 56,463,474 ICESat points over Antarctica to 2,314,167, and to 2,150,776 after final selection with the 3-sigma rule and masking out the frozen ocean for consistent validation of the land mass topography accuracy. The height differences were clipped and assigned by means of the land cover map of Hui et al. (2017a).

\subsection{Blue ice maps}

Blue ice areas (BIAs) are unique to Antarctica and consist of old and compressed ice, extending mainly downwind from protruding rocks (e.g., Orheim and Lucchitta, 1990; Bintanja, 1999). They are scattered across the continent, generally in the vicinity of inland mountain ranges and nunataks as well as coastal regions. Estimates of BIAs are around one per cent of the Antarctic land surface (e.g., Giovinetto, 1964; Winther et al., 2001; Hui et al., 2017a). Due to the reduced presence of air bubbles compared to glacier ice, blue ice absorbs radiation in the red spectrum and reflects the deeper-penetrating blue, causing the ice to shimmer bluish. Significant features include a flat and hard surface which is smooth but often rippled because of wind sublimation. The highly densified ice of BIAs cannot be penetrated by X-Band SAR wavelength (Rott et al., 2017; Zhao and Floricioiu, 2017). Blue ice areas therefore represent relative comparable heights for InSAR and Laser measurements and are well suited to validate the absolute height accuracy of the TanDEM-X DEM in Antarctica.

An Antarctic Land Cover Database (AntarcticaLC2000) using Landsat-7 Enhanced Thematic Mapper Plus (ETM+) imagery from 1999-2003 and (Moderate Resolution Imaging Spectrometer) MODIS data from 2003/04 has been produced by Hui et al. (2017a). This data set consists of three classes: snow/firn (97.8 per cent of the area), ice-free rocks ( 0.537 per cent) and blue ice (1.656 per cent), classified with an overall accuracy of 92.3 per cent (available at: https://zenodo.org/record/826032\# .Wo1zSk2pWUk, last access: 13 June 2020). 
https://doi.org/10.5194/tc-2021-19

Preprint. Discussion started: 15 February 2021

(c) Author(s) 2021. CC BY 4.0 License.

(c) (i)

For an evaluation of the AntarcticaLC2000 data, a more detailed blue ice classification from the Australian Antarctic Data Centre (AADC) was used (Bender and Smith, 2013, updated 2017). In this data set, which is limited to the Prince Charles Mountains in the Lambert Basin (Southern Amery Ice Shelf), areas of blue ice regarded as potential aircraft landing sites were digitized from the Landsat Image Mosaic of Antarctica (LIMA) (USGS, 2008).

In addition, for a test area within this region we performed our own object-based classification based on Landsat-8 Operational Land Imager (OLI) with a similar acquisition time as the TanDEM-X data (December 2013). In the classification process, we made use of the spectral information including snow and glacier indices (Normalized Difference Glacier Index, NDGI; Normalized Difference Snow Index, NDSI) as well as texture information (Gray-Level Co-Occurrence Matrix, GLCM).

\subsection{IceBridge measurements}

Operation IceBridge is an airborne scanning laser altimeter which is bridging the data gap between the ICESat and ICESat-2 missions (Koenig et al., 2010). Since 2009, IceBridge has annually surveyed both the Greenland and Antarctic ice sheets as well as sea ice and Arctic glaciers. Flown at typical altitudes of $500 \mathrm{~m}$, the ATM illuminates a swath width of approximately $140 \mathrm{~m}$, with a footprint size of 1 to $3 \mathrm{~m}$ and along track separation of $2 \mathrm{~m}$ by measuring surface elevation with an accuracy of $10 \mathrm{~cm}$ or better (Krabill et al., 2002). In this study we used IceBridge ATM L2 elevation data (Studinger, 2014, updated 2020) to characterize the edited TanDEM-X DEM, although, TanDEM-X SAR measurements and the airborne laser altimeter measurements of IceBridge differ over the snow pack in their the reflection on the surface and subsurface. Furthermore, the IceBridge program's focus are active glacier areas (Koenig et al., 2010) which lead to temporal changes. Therefore, regarding our error characterization purpose, we carefully reduced the Icebridge data set and selected Icebridge data from the same period and from the most stable regions like the South Pole and the Recovery glacier, both acquired in October 2014.

\subsection{Reference DEMs}

For further model-to-model comparisons we used two actual DEM data sets both covering similar time frames as TanDEMX: the CryoSat's radar altimeter DEM from Slater et al. (2018) and REMA (Howat et al., 2019). The CryoSat-2 DEM is composed of measurements between 2010 and 2016 and is posted at a resolution of $1 \mathrm{~km}$. For our comparison, the TanDEM-X DEM was resampled to $1 \mathrm{~km}$ Antarctic Polar Stereographic grid spacing. The REMA mosaic is constructed from stereoscopic satellite imagery collected by DigitalGlobe's Worldview satellite constellation acquired mostly between 2015 and 2016 and is distributed in Antarctic Polar Stereographic projection in $8 \mathrm{~m}$. For our purposes, we used the resampled version with $1 \mathrm{~km}$ spacing. The vertical reference for all used DEMs is the WGS84 ellipsoid. 


\section{DEM Generation method}

Two processors were involved in the generation of the TanDEM-X DEM product (Wessel, 2018). At first, the Integrated TanDEM-X Processor (ITP) (Fritz et al., 2011; Rossi et al., 2012; Lachaise et al., 2018) interferometrically processed raw data to pre-calibrated, geocoded single-scene DEMs, the so-called RawDEMs. The Mosaicking and Calibration Processor (MCP) performed the final height calibration by a block adjustment (Gruber et al., 2012) and a mosaicking of the corrected single RawDEMs to the final TanDEM-X DEM product (Gruber et al., 2016). The generation of the DEM for Antarctica necessitated a special calibration procedure that we present for the first time in detail in the following sections.

\subsection{Antarctica DEM block adjustment}

The TanDEM-X block adjustment, also called DEM calibration, is conducted by a weighted least-squares adjustment employing ICESat points as well as image tie-points (TPs). Thanks to the excellent calibration of the TanDEM-X system only small offsets and tilts for a single data take remain. They are in the range of few meters, typically most of them even below $\pm 2 \mathrm{~m}$, and are subject to the block adjustment. ICESat points are used as Ground Control Points (GCPs) to adjust the TanDEM-X DEM to the absolute height reference. Tie points are located within a $3 \mathrm{~km}$ range overlap between two adjacent acquisitions and are used to derive height differences. For a tie point the height of an area of approximately $1 \mathrm{~km} \times 1 \mathrm{~km}$ is evaluated and the median height is chosen for comparison (Huber et al., 2010).

However, SAR signals penetrate into the ice sheet. The penetration depth depends on the wavelength of the radar and the snow and ice properties (Fischer et al., 2020). Consequently, the laser altimeter derived ICESat elevations and SAR measurements are biased by some meters (see Fig. 2). Therefore, ICESat points have to be applied in a different way to avoid an artificial raise or even deformation of the resulting DEM upwards to the ground control points. For Greenland, the calibration of the RawDEMs was performed solely with ICESat points measured in the outer coastal rock regions (Wessel et al., 2016), in the inner ice sheet tie points link the data takes to each other. In contrast, Antarctica's coast is mostly covered by ice and therefore, the ICESat and radar elevations do not represent the same elevation because they are biased by penetration bias. For Antarctica, we developed a new innovative approach relying on areas with homogeneous backscattering characteristics and therewith predominantly homogeneous penetration bias (HPB), see Fig. 2. Figure 3 describes the workflow for this new DEM adjustment of InSAR data takes over glaciated terrain.

In a first step, the HPB areas must be identified in the inner Antarctic continent with help of the Radarsat-1 amplitude mosaic (Jezek, 2002). TanDEM data takes over a homogeneous amplitude area located probably in the dry snow zone were grouped into a so-called adjustment block, i.e. into a consolidation of several data takes over one region. Then, the data takes of this potential homogeneous penetration block $L$ were adjusted by a nominal least-squares adjustment towards the GCPs with the standard observation equation for TanDEM-X heights at GCP points (Gruber et al., 2012) that are aiming at zero height differences given by the equation

$\left[H_{i, \mathrm{~J}}+\hat{x_{J}}\right]-H_{i, \mathrm{GCP}}+\hat{v}_{i}=0$ 


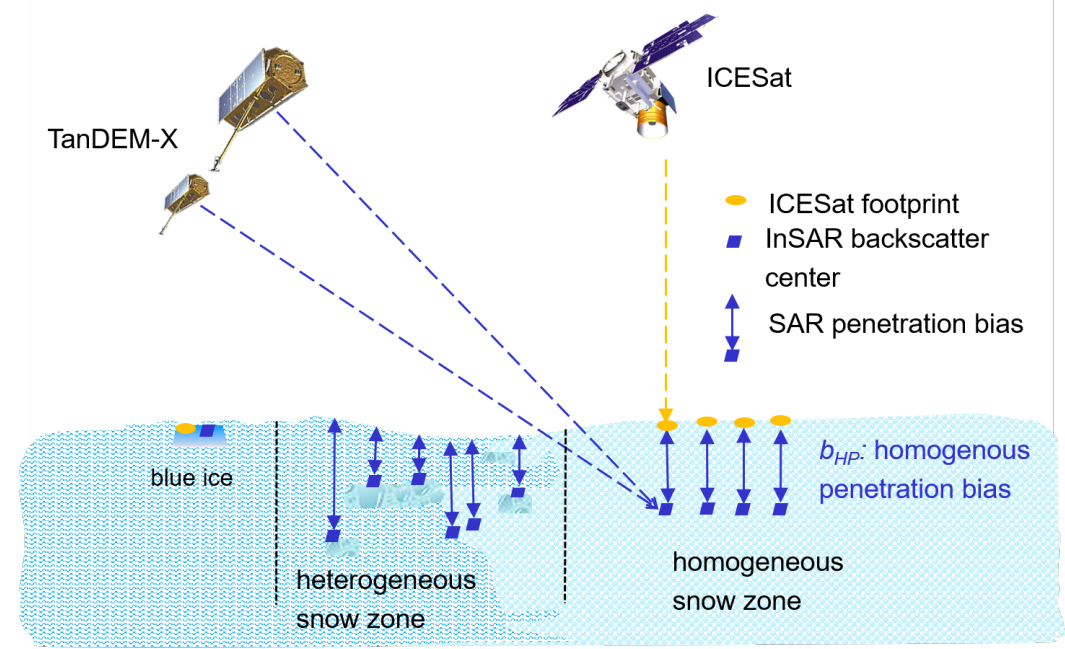

Figure 2. Schematic characterization of the snow zone dependent surface penetration of X-Band SAR into the ice sheet. $b_{H} P$ denotes a homogeneous penetration bias for homogeneous snow zones.

where $H_{i, \mathrm{~J}}$ is the observed height $H_{i}$ of data take $J, \hat{x_{J}}$ is the adjusted unknown correction parameter for data take $J$, and $\hat{v}_{i}$ are the summarized residuals. Due to the difficult conditions on ice sheets for Antarctica only offsets $a$ were determined $(\hat{x}=\hat{a})$. After this, the mean height difference between TanDEM-X and ICESat elevations was calculated for all data takes of the whole potential homogeneous penetration block. Though, having a mean of several meters, the standard deviation of the height differences $\left(S T D_{d H}\right)$ should be low for these blocks and can serve as measure for a homogeneous InSAR penetration. The extent of the input scenes was iteratively modified yielding standard deviations below $1 \mathrm{~m}$. Finally, we identified 11 homogeneous penetration bias blocks (Fig. 4 in red). For the HPA blocks the mean penetration bias and standard deviations vary from $-1.68 \mathrm{~m}$ to $-5.66 \mathrm{~m}$ and 0.92 to $1.20 \mathrm{~m}$ respectively. They are located in the inner Antarctic and well distributed over the continent to serve as ground control for the adjacent blocks.

In a nominal least-squares adjustment the estimated offsets would be applied and the DEM data takes would be lifted towards the ICESat GCPs. In order to avoid uplifting effects, for each HPB block $L$ the mean penetration bias $b_{H P, L}$ based on the difference between TanDEM-X and ICESat elevations

$b_{H P, L}=1 / n \sum_{i=0}^{n} H_{i, \mathrm{~J}}-H_{i}^{\mathrm{GCP}}$,

is calculated as a constant bias for the entire block. The application of $b_{H P, L}$ to the individual data takes, sets the height level of the adjusted heights back to a mean InSAR height below the surface

$\hat{H}_{i, \mathrm{~J}}^{b_{H P, L}}=\left[H_{i, \mathrm{~J}}+\hat{x}\right]+b_{H P, L}$.

Note that $b_{H P, L}$ is negative. 
https://doi.org/10.5194/tc-2021-19

Preprint. Discussion started: 15 February 2021

(c) Author(s) 2021. CC BY 4.0 License.

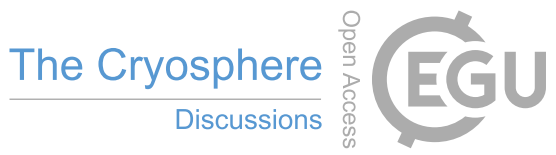

(c) (i)

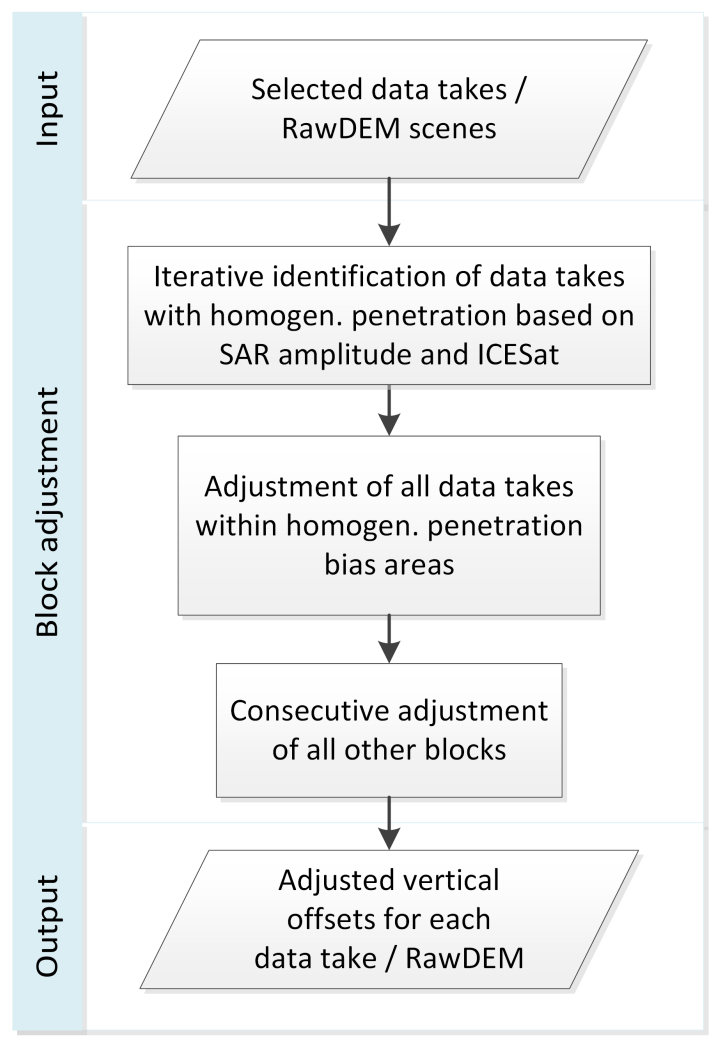

Figure 3. Workflow for DEM adjustment of TanDEM-X DEM data takes in Antarctica.

Starting from these ground control blocks, all other DEM acquisitions were adjusted relying solely on tie points and on already adjusted heights from neighboring blocks that were used as ground control point heights using Eq. 1. Further on, the observation equation for tie points also sets the height difference of two heights $H_{J}^{T P}$ of data take $J$ and $H_{K}^{T P}$ of data take $K$ to zero

$\left[H_{i, \mathrm{~J}}^{T P}+\hat{x}_{J}\right]-\left[H_{i, \mathrm{~K}}^{T P}+\hat{x}_{K}\right]+\hat{v}_{i}=0$.

The DEM calibration process of the 50 blocks without external GCPs (Fig. 4 in blue) started in East Antarctica and proceeded in two directions, clock-wise and counter-clockwise, re-unified in the West Antarctica. In summary, the DEM calibration strategy for Antarctica can be subdivided into two parts:

- First, all homogeneous penetration bias blocks are adjusted by maintaining the mean penetration with respect to ICESat.

- Second, all other DEM acquisitions are adjusted relying solely on tie points and on already adjusted heights from other blocks. 


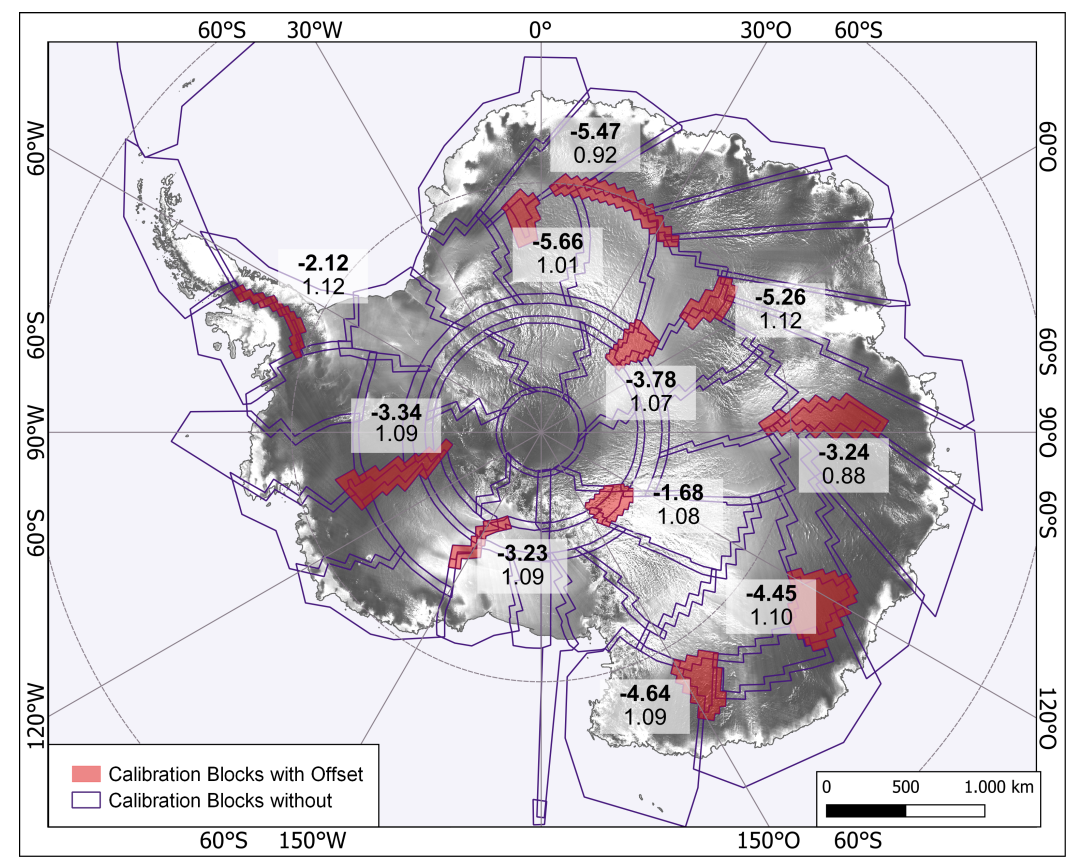

Figure 4. DEM Calibration blocks for Antarctica. The 11 red blocks were calibrated first towards ICESat and then the mean SAR penetration bias was substracted. Bold numbers: mean penetration bias per homogeneous penetration block. Italics: standard deviation of TanDEM-X to ICESat elevations. The red blocks were used as ground control areas for the remaining blocks.

\subsection{DEM Mosaicking concept}

The aim of the DEM Mosaicking is the fusion of individual DEM scenes into a complete and homogeneous elevation model. Basically, all acquired data were considered in the TanDEM-X DEM product generation process to reduce the random height error (HE). The individual pixels were mosaicked according a HE-weighted average:

$h_{i}=\frac{\sum_{k=1}^{K} \frac{1}{\sigma_{H E, k}^{2}} h_{k}}{\sum_{k=1}^{K} \frac{1}{\sigma_{H E, k}^{2}}}$

For each input elevation $h_{k}$, the corresponding weight is derived from its height error, a standard deviation estimate $\sigma_{H E, k}$ obtained from the interferometric coherence. The estimated calibration correction parameters for each acquisition were applied in advance to each single input DEM scene. In case of larger height discrepancies induced for example by phase unwrapping errors, the TanDEM-X mosaicking approach performs a grouping of all input height measurements into several height intervals (Gruber et al., 2016). This allows for the identification of the most reliable height interval based on InSAR specific parameters to be used for mosaicking.

Nevertheless, some continuous changes near the coast could be observed even though the acquisition time span was relatively short. Melting, floating ice sheets and glacier advance that caused height disparities between the input data and were some of 


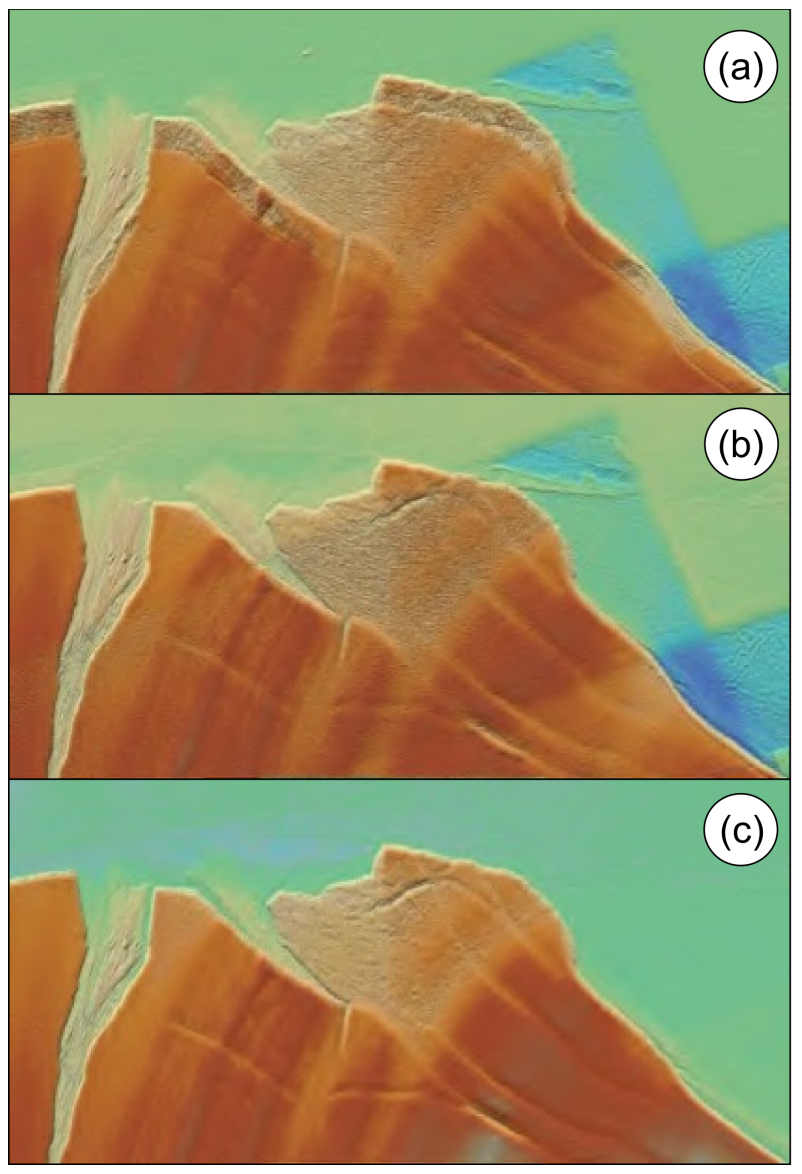

Figure 5. DEM mosaicking iterations at Filchner ice shelf. a) first mosaicking with all acquisitions from mid 2013 and mid 2014, b) second mosaicking with 2014 acquisitions only, and c) third mosaicking with 2014 ascending acquisitions only.

the main challenges for the mosaicking. Thus, the quality assessment of the mosaicking results had to be conducted with regard to these conflicting measurements, with the consequence that contradicting measurements were taken out. In a first step of this iterative quality control process, all acquisitions were mosaicked in the same way as for the standard TanDEM-X DEM generation. Then, in a follow-on step conflicting DEM scenes were identified and removed for a second mosaicking run. This identification and mosaicking step had to be repeated one to three times. Fig. 5 illustrates such a first all-in mosaicking result at the Filchner ice shelf and its iterative improvement by omitting some contradicting scenes. The initial mosaicking resulted in multiple mappings of the ice shelf front and the crevasses caused by the ice drift at different acquisition times (Fig. 5a). In the first improvement step the acquisitions of mid-2013 were omitted to reduce the effects of ice drifts between 2013 and 2014 (Fig. 5b). In a second iteration, additionally all scenes from the crossing orbits (in this case with a descending orbit look direction from mid-2014) were taken out, eliminating edge effects and providing a smoother DEM (Fig. 5c). 


\section{DEM Editing}

The global TanDEM-X DEM is an unedited DEM created from SAR interferometry. This implies, among other effects, that open water surfaces show noisy relief due to low coherence and backscatter. In order to enhance the usability for further applications such as ortho-rectification, ice velocity or mass balance estimation a filling and editing of the TanDEM-X DEM was conducted with special focus on the coasts. These improvements are made under the TanDEM-X PolarDEM framework for the provision of derivatives of the global TanDEM-X DEM for Polar Regions. The derivatives currently include a filled and edited version of the TanDEM-X DEM for Antarctica as described in this section. It will be supplemented in the future by the TanDEM-X PolarDEM for the Arctic, especially over Greenland, with single year coverages and penetration bias corrected DEMs.

\subsection{DEM gap filling}

Although the acquisition strategy planned at least two complete acquisitions, several factors contributed towards insufficient RawDEM quality or missing acquisitions (e.g. inappropriate height of ambiguity for dual-baseline phase unwrapping, loss of data during downlink, a more detailed list is given in Rizzoli et al. (2017)). For Antarctica, this in turn yielded 16 small data gaps within the TanDEM-X DEM with a total size of $13,200 \mathrm{~km}^{2}$ affecting 52 geocells as displayed in Fig. 6. Additional

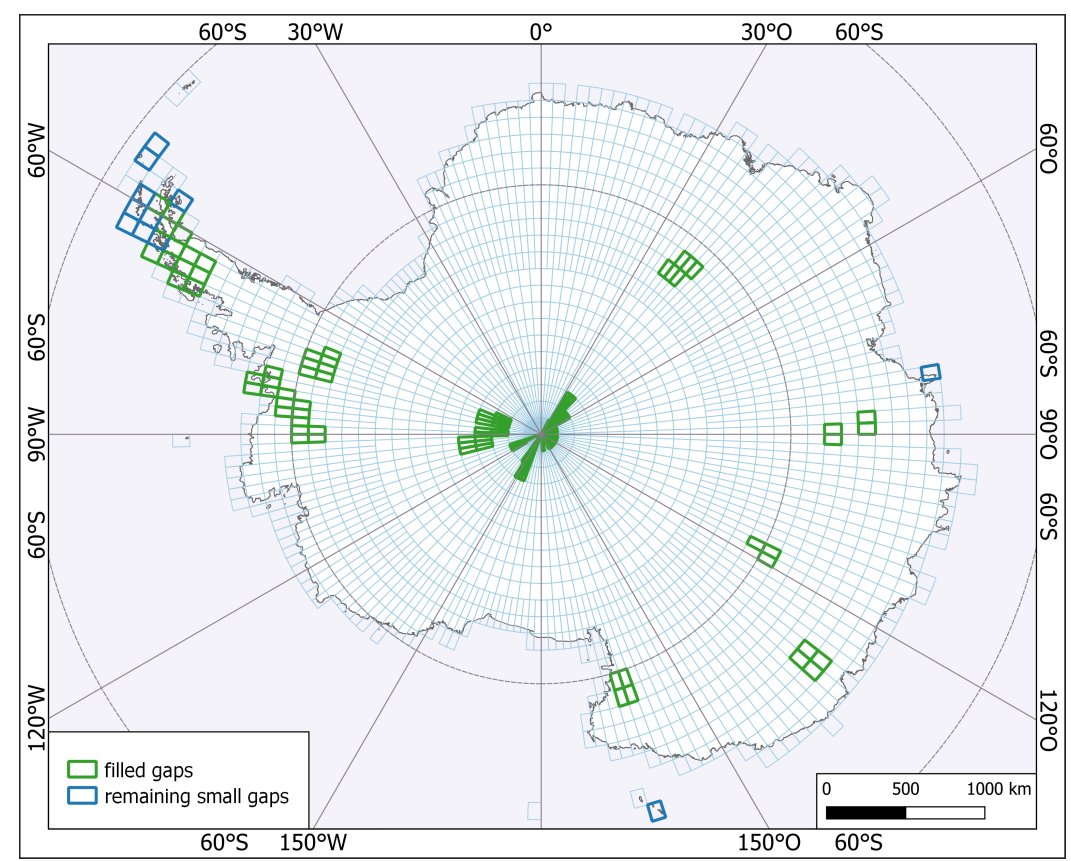

Figure 6. TanDEM-X DEM geocells after DEM gap filling with new acquisitions: Geocells with gaps that could be filled (in green). Geocells with remaining smaller gaps after DEM gap filling (in blue). 
https://doi.org/10.5194/tc-2021-19

Preprint. Discussion started: 15 February 2021

(c) Author(s) 2021. CC BY 4.0 License.

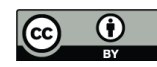

acquisitions were subsequently scheduled for these gaps as DEM geocells containing gaps were identified during the quality

assurance process within the Ground Segment. For Antarctica these acquisitions were performed from mid-2016 to mid-2017.

A major improvement in coverage could be achieved by incorporating 20 new acquisitions for Antarctica (see geocells with improved coverage in Fig. 6). All new DEM scenes were calibrated onto the existing DEM scenes and all related geocells were re-mosaicked including all previous and new DEM scenes. The resulting filled TanDEM-X DEM built the basis for later editing. Finally, a coverage completeness of 99,991 per cent of the total Antarctic land mass could be achieved. Note that remaining smaller gaps with a total size of $1,200 \mathrm{~km}^{2}$ are located over islands, while the rest of mainland Antarctica is completely covered by TanDEM-X elevation data.

\subsection{Semi-automatic coastline delineation}

In order to demarcate the Antarctic Ocean, an outline of Antarctica was derived based on the 0.4 arcsecond (approximately $12 \mathrm{~m}$ ) TanDEM-X elevation (DEM) and amplitude (AMP) layers. This outline represents the separating line between open sea and ice shelf or land areas rather than the actual divide between land and water. For the sake of convenience the term 'land' comprises the ice shelf as well as land areas in the following. The TanDEM-X derived outline therefore distinguishes between open sea and land and is called "TanDEM-X coastline". During the DEM editing, homogeneous geoid undulations were assigned to the open sea areas while identified land areas were further edited as described in Sect. 4.3.

Figure 7 illustrates the workflow for the tile based coastline delineation. The input data includes the 0.4 arcsecond TanDEMX elevation (DEM) and amplitude (AMP) layers of the TanDEM-X DEM product (Wessel, 2018). Additionally, the coastline from the Scientific Committee on Antarctic Research (SCAR) provided via the Antarctic Digital Database (ADD) is utilized as a proxy for the coastline (Scientific Committee on Antarctic Research, 2019). For integration into the workflow the SCAR coastline was rasterized in 0.4 arcsecond. In the following, this rasterized proxy is referred to as SCAR water mask. It is adapted where necessary by adding user defined sea and ice shelf or land areas, respectively. Note that shelf ice or land areas will only survive where corresponding seeds exist within the water mask. Moreover, a set of variable configuration parameters can be set for each tile, e.g. AMP and DEM thresholds. Therefore, the approach is referred to as semi-automatic since tile specific conditions may require individual adjustments.

In a first processing step, a seed land mask is derived from the AMP (Fig. 8a) and DEM (Fig. 8b) layer using default or user specific thresholds. For the amplitude layer land areas are assumed to have values above a default threshold of, for example $100 \mathrm{DN}$. The threshold for the elevation layer is based on the mean geoid height plus a default threshold of, for example $10 \mathrm{~m}$, i. e. land areas are assumed to be higher than the mean sea level plus a defined margin. For the seed land mask both thresholds (AMP and DEM) have to be fulfilled (Fig. 8c). In the second processing step, the rasterized SCAR coastline is taken as starting line and is gradually adjusted to the extent of the TanDEM-X seed land mask using dilation and erosion operations (Fig. 8c). In other words, the SCAR coastline is extended towards the open sea while TanDEM-X indicates land and extended towards land while TanDEM-X indicates water. This approach also eliminates false positive errors in the TanDEM-X seed land mask (e.g. presumed islands which are actually icebergs) as well as false negative errors (e.g. presumed water areas within land which are indicated due to low amplitude values on land ice). Afterwards, filter operations were applied to smooth the resulting coastline 
https://doi.org/10.5194/tc-2021-19

Preprint. Discussion started: 15 February 2021

(c) Author(s) 2021. CC BY 4.0 License.

(c) (i)

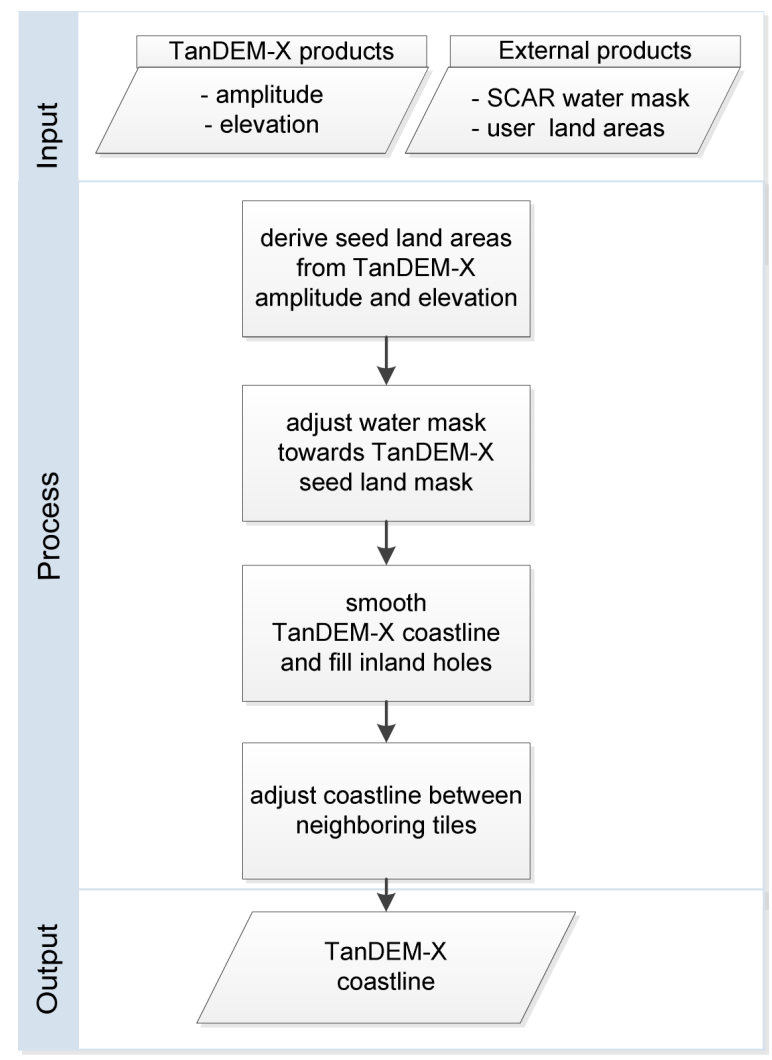

Figure 7. Workflow for (semi-)automatic TanDEM-X coastline delineation.

and fill remaining inland holes in the land mask. Neighboring tiles may show misalignment in their coastlines due to varying configuration parameters and tile based processing. Therefore, an automatic correction is applied to match detected coastlines of adjacent tiles. The resulting outline (Fig. 8d) is utilized during the following editing process in order to replace open water areas by geoid undulations. The length of the derived TanDEM-X coastline of Antarctica is $62,971 \mathrm{~km}$. It should be noticed that the generated outline reflects the conditions as observed by the TanDEM-X mission mainly in the years 2013 and 2014.

\subsection{Semi-automatic DEM Editing}

All 0.4 arcsecond TanDEM-X DEM tiles of Antarctica run through the general editing workflow developed for TanDEM-

$270 \mathrm{X}$ DEMs which is described in Huber et al. (2015). Focus is on edge-preserving smoothing as well as the void and outlier interpolation, especially for areas with strong relief located mainly in outer Antarctica.

- Edge-preserving smoothing: An edge-preserving smoothing was applied to the whole dataset. On the one hand, this provides a smoother dataset by reducing local noise. On the other hand, linear structures like ridges and peaks are preserved as the smoothing does not weight pixels on different sides of these linear DEM features. 


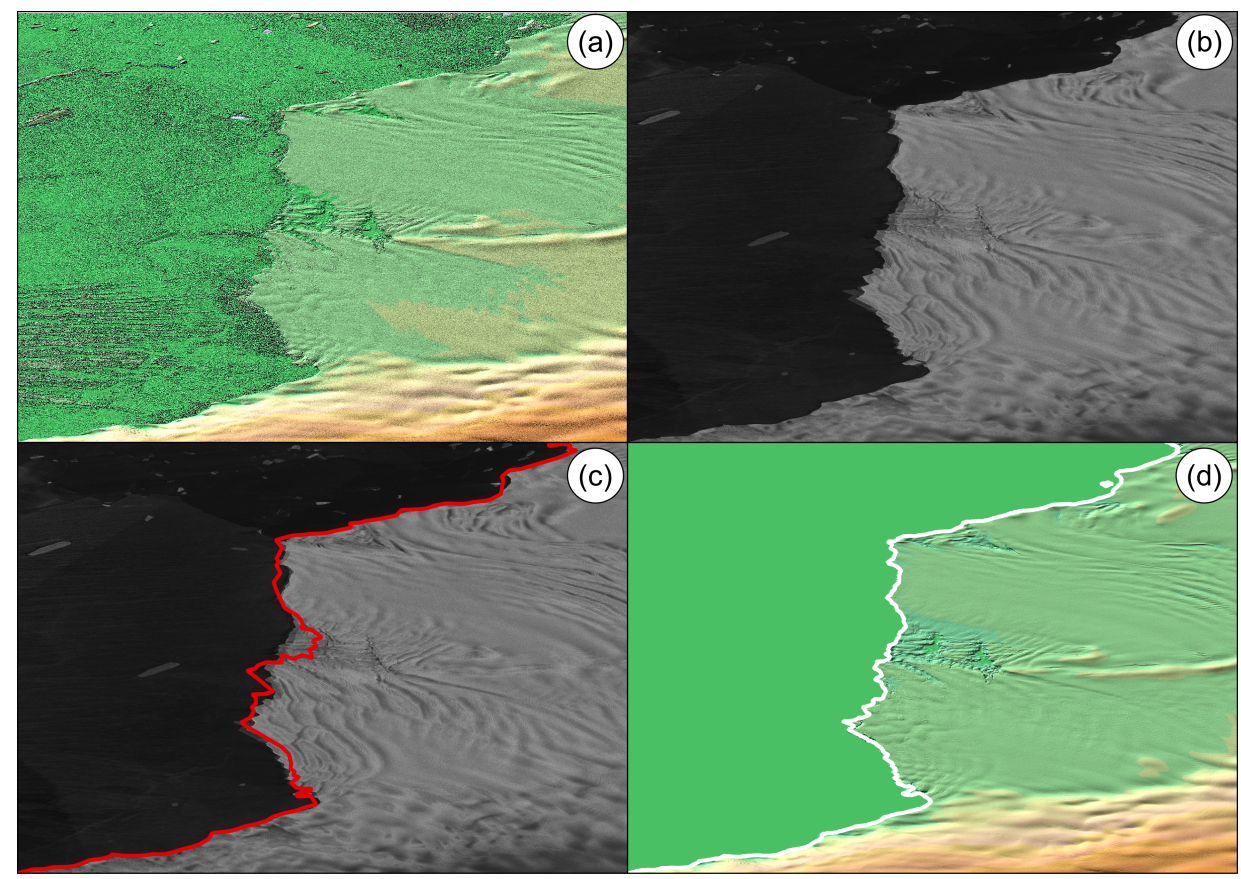

Figure 8. TanDEM-X semi-automatic coastline delineation - Example of Mackenzie Bay, Amery ice shelf, a) + b) input: DEM and amplitude of TanDEM-X DEM, c) SCAR coastline superimposed in red, and d) TanDEM-X coastline derived from DEM and amplitude in white, superimposed on tailored and geoid filled DEM.

- Outlier and void interpolation: Due to the processing characteristics of radar data, single outlier pixels may be present in the elevation data. Although multiple radar acquisitions are fused during the TanDEM-X DEM generation (Gruber et al., 2016), an outlier detection and local interpolation is implemented. The outlier pixels are defined based on local statistics and interpolated with the same approach as for the smoothing. However, the center pixel, which is supposed to be unreliable, receives zero weight and is therefore neglected.

Also, void pixels caused by low coherence may be present. They are interpolated from surrounding elevations by a variance-weighted averaging taking into account the variance values provided within the height error map as well as a variogram model describing the degree of spatial dependence of the neighboring pixels.

- Integration of geoid undulations for the ocean mask: To provide heights for the ocean, the geoid undulation $N$ is chosen. The geoid undulation represents the deviation of the geoidal height $h_{M S L}$ from the ellipsoidal height $h_{\text {ell }}$

This ensures that when ellipsoid heights are converted to mean sea level, the ocean height values in geoid heights correspond to zero mean sea level. The geoid undulations are extracted from the commonly used Earth Gravitational Model 2008 (EGM2008 Development Team, 2012). In order to support a smooth transition between geoid and TanDEM- 
X heights a buffer zone of approximately $200 \mathrm{~m}$ is defined starting from the coastline towards the open sea. Within this buffer zone the geoid undulations and TanDEM-X heights are combined by distance weighted averaging.

- Reduction and resampling to $90 \mathrm{~m}$ : The TanDEM-X PolarDEM of Antarctica was first reduced to 1 arcsecond pixel spacing by an unweighted mean of the underlying 0.4 arcsecond pixels. For more convenient data handling the DEM in geographic coordinates subdivided into 2,621 tiles south of $60^{\circ} \mathrm{S}$ was transformed into the more suitable Cartesian coordinates in the Antarctic Polar Stereographic projection (EPSG:3031) with a pixel spacing of $90 \mathrm{~m}$ (Fig. 9).

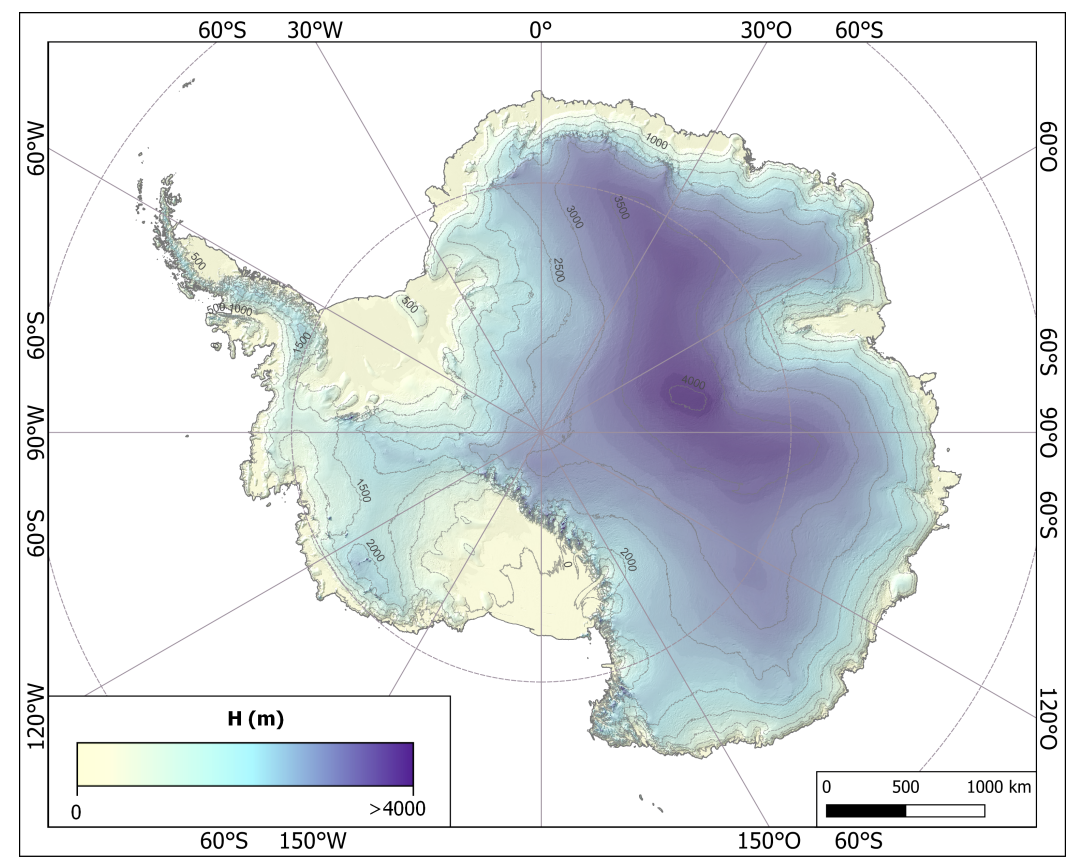

Figure 9. Gap-filled and edited TanDEM-X PolarDEM 90m of Antarctica in color-coded elevations.

\section{Results and discussion}

The evaluation and error characterization of the vertical accuracy of the TanDEM-X PolarDEM of Antartica is based on the comparison with ICESat, IceBridge and other DEM data. The results are detailed in the following.

\subsection{Quality characterization with ICESat}

The resulting accuracy numbers in comparison with ICESat are given in Table 1. As the height differences are defined as TanDEM-X height minus ICESat height, negative height differences, like the mean of $-3.22 \mathrm{~m}$, mean that the InSAR heights are below the laser-based ICESat heights. This can mainly be explained by the SAR signal penetration into ice in the order of a few meters. The deepest penetration bias into the glaciated surface can be found at the highest elevations in the central 


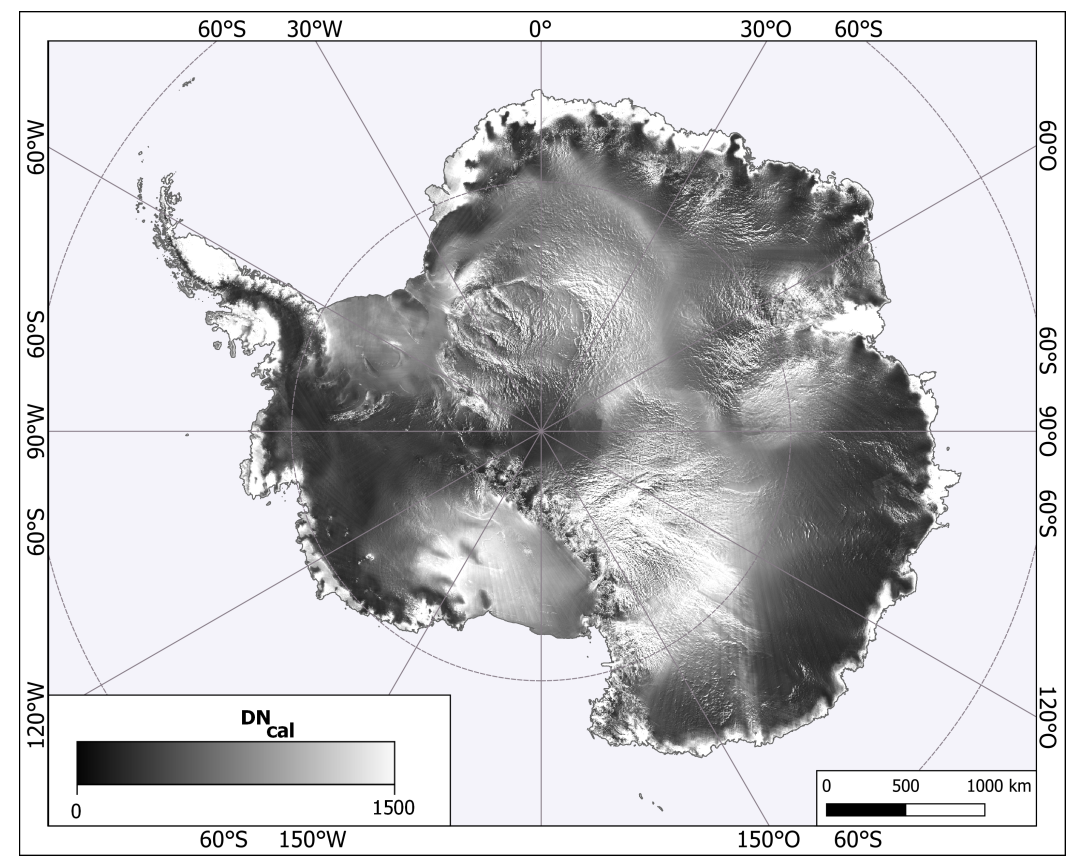

Figure 10. TanDEM-X PolarDEM 90m amplitude mosaic of Antarctica.

east Antarctic ice sheet (AIS) (Fig. 11). Here, the temperatures are coldest (Macelloni et al., 2019; Scambos et al., 2018) and the SAR signal penetrates the most in dry, cold firn (Ulaby et al., 1986), whereas the coastal areas show lower penetration which clearly corresponds to the brighter reflecting perculation areas in the amplitude mosaic (Fig. 10). This variation of the SAR penetration over whole AIS raises the absolute linear error (LE90) to $6.25 \mathrm{~m}$ that is calculated by sorting the absolute differences thresholded by $90 \%$ of the values. A LE90 of $6.25 \mathrm{~m}$ is still below the mission requirement of $10 \mathrm{~m}$ LE90 for TanDEM-X DEM, though, the absolute height accuracy of all geocells world-wide without Antarctica yields in an impressive LE90 value of around $3 \mathrm{~m}$ (Rizzoli et al., 2017).

To analyze these variations the absolute height statistic of the TanDEM-X DEM is subdivided into three different land-cover classes: blue ice areas, snow/firn and ice-free rocks (Table 1). Looking at the histograms of the height differences (Fig. 12) the most symmetric distribution around zero is given for the blue ice class. Here, we have the lowest absolute median with $-0.25 \mathrm{~m}$. In contrast, the class snow and ice shows a slightly uneven distribution with a negative median of $-3.38 \mathrm{~m}$ due to different penetration biases on different snow facies. Looking at the class ice-free rocks there seems to exist two maxima, one around $-1.5 \mathrm{~m}$ and one around $2.5 \mathrm{~m}$. However, the differences of the class ice-free rocks should rather be distributed around zero. The points contributing to this class lie mainly in the Transantarctic Mountains and at the Antarctic peninsula. The ICESat differences in Fig. 11 show positive height differences especially the northern part of the Peninsula, so these points contribute to the peak around $2.5 \mathrm{~m}$ in Fig. 12c). 
https://doi.org/10.5194/tc-2021-19

Preprint. Discussion started: 15 February 2021

(c) Author(s) 2021. CC BY 4.0 License.

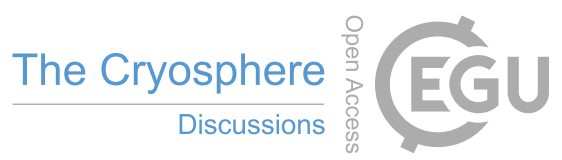

Table 1. Accuracy numbers for height differences TanDEM-X minus ICESat and for the individual classes blue ice areas, snow/firn and ice-free rocks according to LC2000.

\begin{tabular}{lrrrr}
\hline $\begin{array}{l}\text { Accuracy } \\
\text { measure }\end{array}$ & $\begin{array}{r}\text { whole area } \\
(\mathrm{m})\end{array}$ & $\begin{array}{r}\text { BIA } \\
(\mathrm{m})\end{array}$ & $\begin{array}{r}\text { snow/firn } \\
(\mathrm{m})\end{array}$ & $\begin{array}{r}\text { ice-free } \\
\text { rocks } \\
(\mathrm{m})\end{array}$ \\
\hline Mean & -3.22 & -0.32 & -3.28 & -0.73 \\
STD & 2.56 & 2.46 & 2.51 & 2.77 \\
RMSE & 4.11 & 2.48 & 4.13 & 2.87 \\
LE90 & 6.25 & 3.74 & 6.26 & 4.70 \\
Median & -3.33 & -0.25 & -3.38 & -0.77 \\
NMAD & 2.50 & 2.02 & 2.46 & 3.15 \\
\#points & $2,150,776$ & 35,804 & $2,102,052$ & 6,428 \\
\hline
\end{tabular}

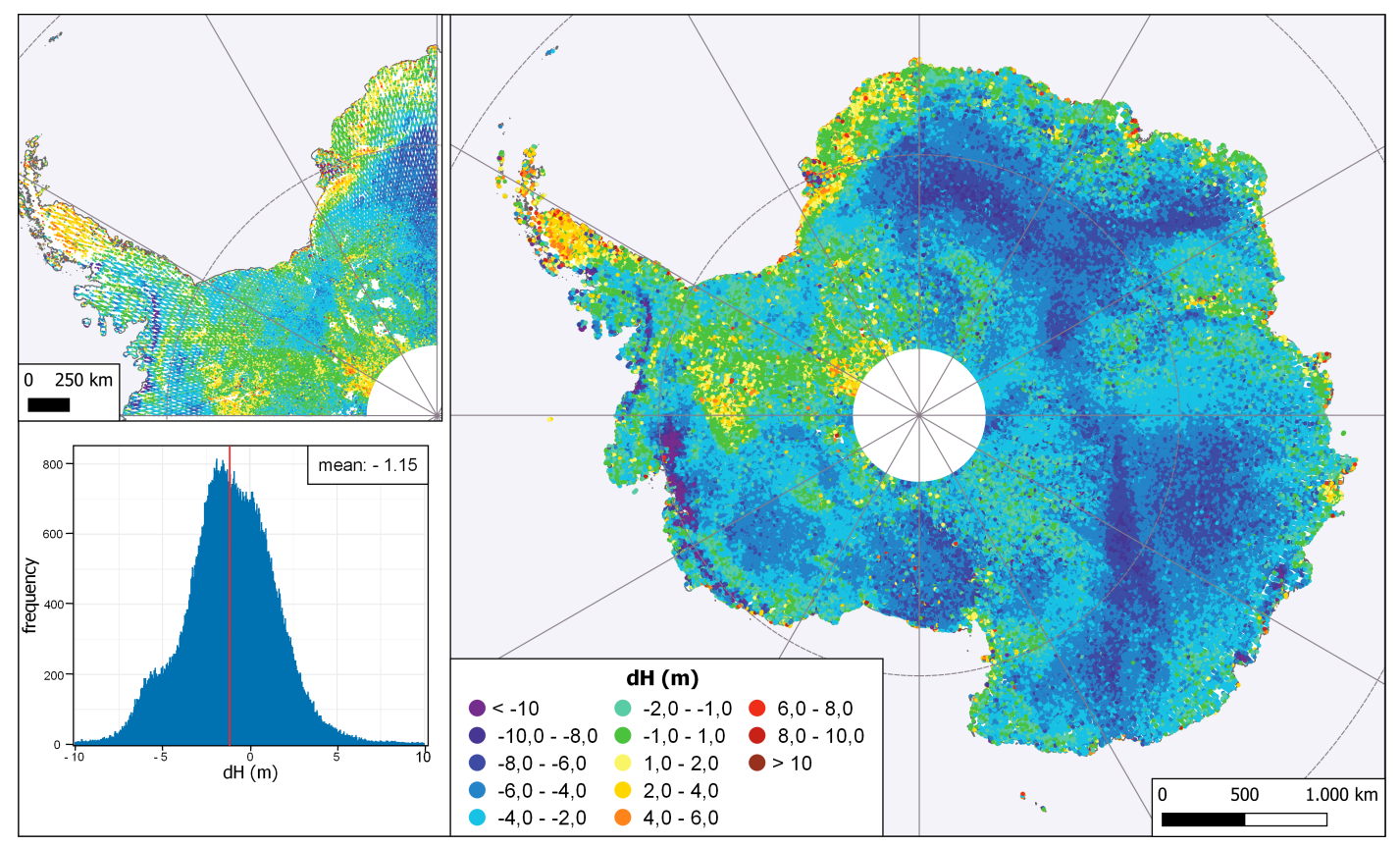

Figure 11. Height differences ICESat GLA14 elevations minus TanDEM-X DEM over all of Antarctica. Panel on the left: a detailed view on the quadrant of the Antarctic Peninsula with its corresponding histogramm of height differences.

Also in the western AIS, another effect is prominent in a closer analysis of the the height differences to ICESat in Fig. 11: in the area around West $90^{\circ}$ the height differences increase from negative values to zero meters. Also the differences of the BIA (Fig. 13) increase in this area in a way that the TanDEM-X elevations are even some meters above ICESat elevations, which is quite unrealistic for a larger area. These points suggest that the DEM calibration is not perfect in Western Antarctica and a raise of the DEM by some few meters occured. 
Another interesting feature in the differences to ICESat (Fig. 11) can be found in central Antarctica. Here, lower and stronger penetration biases alternate in a ray-structure centered at the Pole. It should be noted that the latitudes from $-88^{\circ}$ to $-90^{\circ}$ over Antarctica have no ICESat points as the ICESat system did not cover this region. The stronger penetration biases are related to darker areas in the amplitude mosaic and lower penetration biases to brigthter amplitude areas (Fig. 10). Possibly wind dynamics, form together with the underlying topography ice with special characteristics (personal communication with Andrew Shepherd, 3 May 2019).

Generally, these height differences between ICESat and TanDEM-X confirm that the chosen DEM calibration strategy was justified to maintain the different penetration effects and not to raise the DEM towards ICESat elevations to prevent a deforming of the DEM.
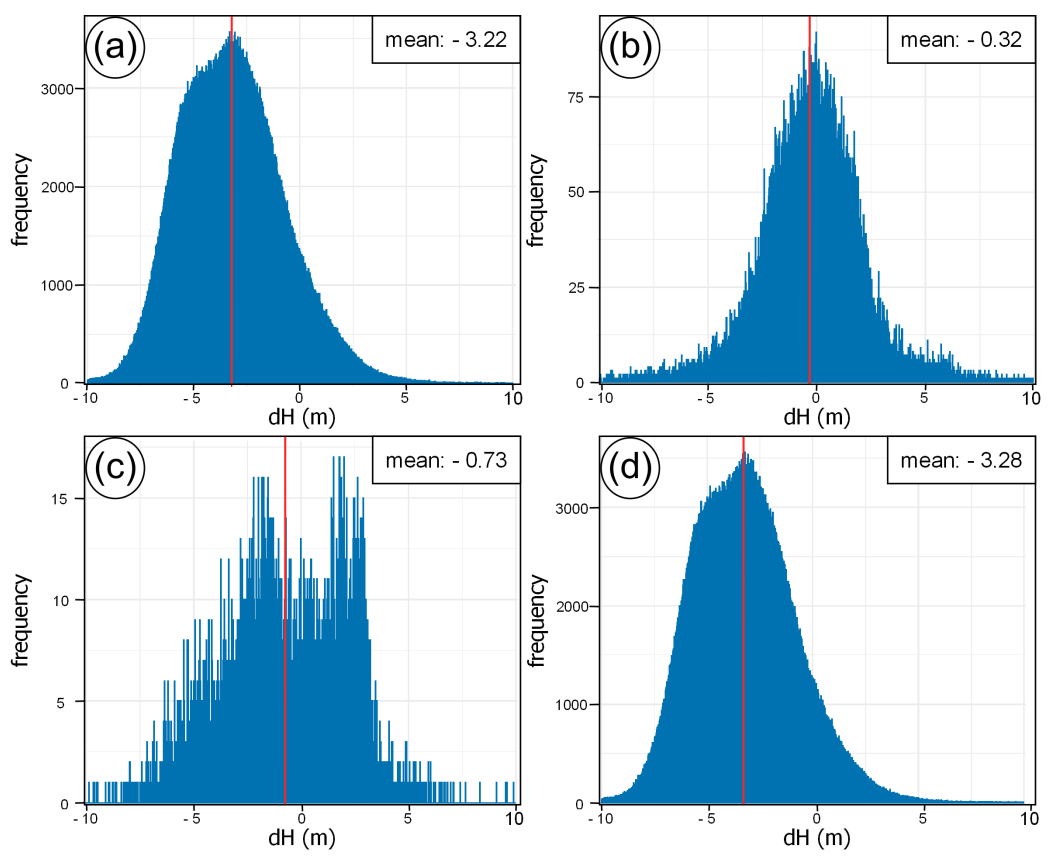

Figure 12. Histograms of height differences for TanDEM-X DEM minus a) all ICESat elevations, b) ICESat elevations on blue ice areas, c) ICESat elevations on ice-free rocks, and d) ICESat on snow-firn. Assigned according to the land cover map of Hui et al. (2017a).

\subsection{Validation with ICESat on blue ice areas (BIAs)}

As shown in Sect. 5.1, BIAs are ice areas that the X-Band SAR signals do not penetrate. Therefore, a validation of the absolute vertical accuracy of the final TanDEM-X PolarDEM can be achieved through an evaluation with ICESat over BIAs. The results obtained in the previous section rely on a BIAs mask from the AntarcticLC2000. For a deeper understanding, we conducted an analysis over a smaller region of the Amery ice shelf with a more accurate reference BIA map from the Australian Antarctic Data Centre (AADC) and an own supervised classification optimized for this region. In Fig. 14 all classification results for blue 


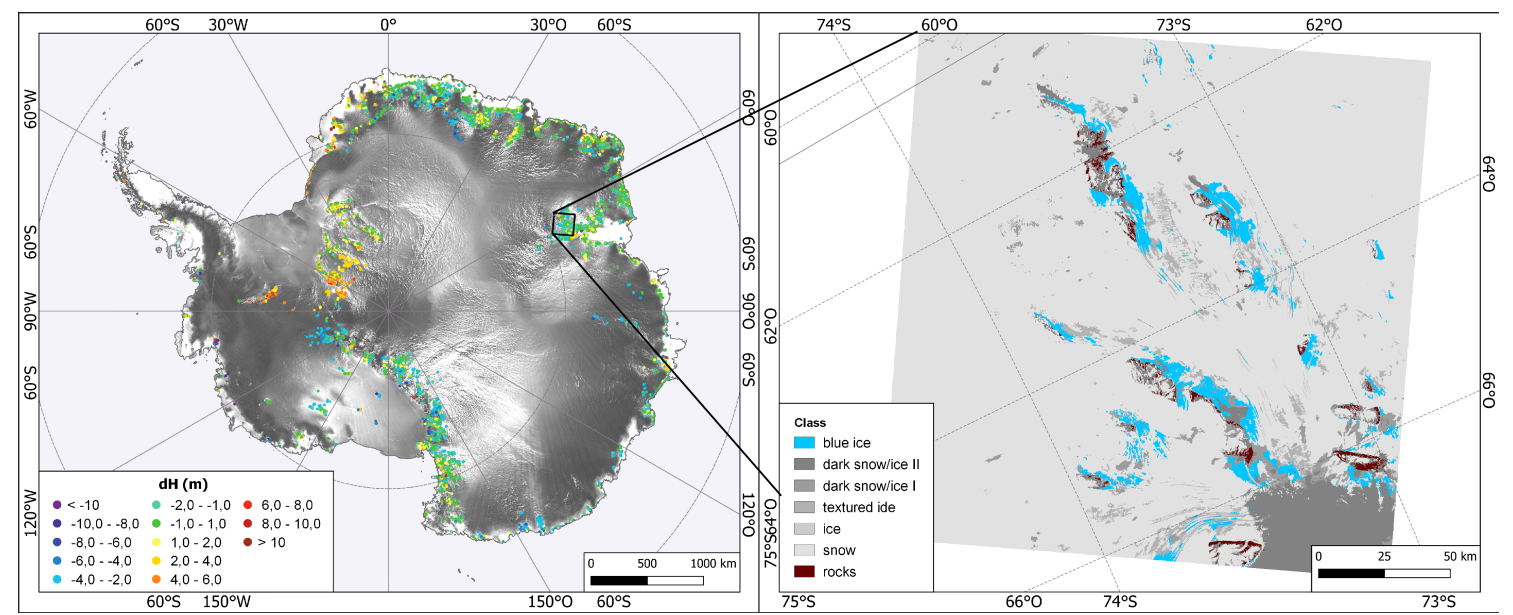

Figure 13. Left: Distribution of TanDEM-X minus ICESat differences on LC2000-BIAs. Right: study area for BIA classification, Southern Prince Charles Mountains/Amery ice shelf.

ice for this subset are displayed, overlaid with TanDEM-X minus ICESat height differences. Over the BIAs, the differences are around zero (green ICESat points) compared to a SAR signal penetration of several meters outside the BIAs. A visual inspection of the blue ice classifications in the Southern Prince Charles Mountains test area near Amery ice shelf show that the AntarcticaLC2000 classification (Fig. 14d) identified much larger BIAs, whereas the AADC map (Fig. 14c) seems to underestimate these. The purpose of our classification (Fig. 14b) is a more precise delimitation of visible BIAs based on Landsat-8 imagery. It includes additional classes such as highly textured ice or dark snow/ice for a further differentiation.

For all three BIA classifications in the test area, we calculated height accuracy measures (Table 2). It could be shown that for all three classifications within this small subset the BIAs classes show the lowest mean values. The height accuracy measures in Table 2 confirm the deepest mean penetration for BIAs for AntarcticaLC2000 which is in line with the visual inspection of the data.

For our proposed classification, the mean difference between TanDEM-X and ICESat is only $-0.4 \mathrm{~m}$ on BIAs, compared to $-2.74 \mathrm{~m}$ on snow. On dark snowy/icy and textured areas, the mean difference is still more than twice that of BIAs $(-0.84 \mathrm{~m})$, with highly textured ice showing the greatest difference within this group $(-1.43 \mathrm{~m})$. Areas with a high reflectivity in the shortwave spectrum are generally adjacent to BIAs and show just a small difference between TanDEM-X and ICESat (-0.47 m). The result for the AntarcticaLC2000 data set for all of Antarctica (Table 1) shows that despite the presumed overestimation of BIAs, the height difference between TanDEM-X and ICESat is significantly smaller (-0.32 $\mathrm{m}$ ) than for snow/firn (-3.28 $\mathrm{m})$ or ice-freerocks $(-0.73 \mathrm{~m})$. Though the AntarcticaLC2000 data set performed worse in the local Amery study test site (with a mean of $-1.01 \mathrm{~m}$ compared to more fine-tuned classifications with mean values of $-0.29 \mathrm{~m}$ and $-0.40 \mathrm{~m}$ respectively), it is the only one with a complete coverage and the results for all of Antarctica show an impressive mean of $-0.32 \mathrm{~m}$ offset and a mean standard deviation of $2.46 \mathrm{~m}$ (Table 1). These findings are inline with first results from literature (Zhao and Floricioiu, 2017) 
https://doi.org/10.5194/tc-2021-19

Preprint. Discussion started: 15 February 2021

(c) Author(s) 2021. CC BY 4.0 License.

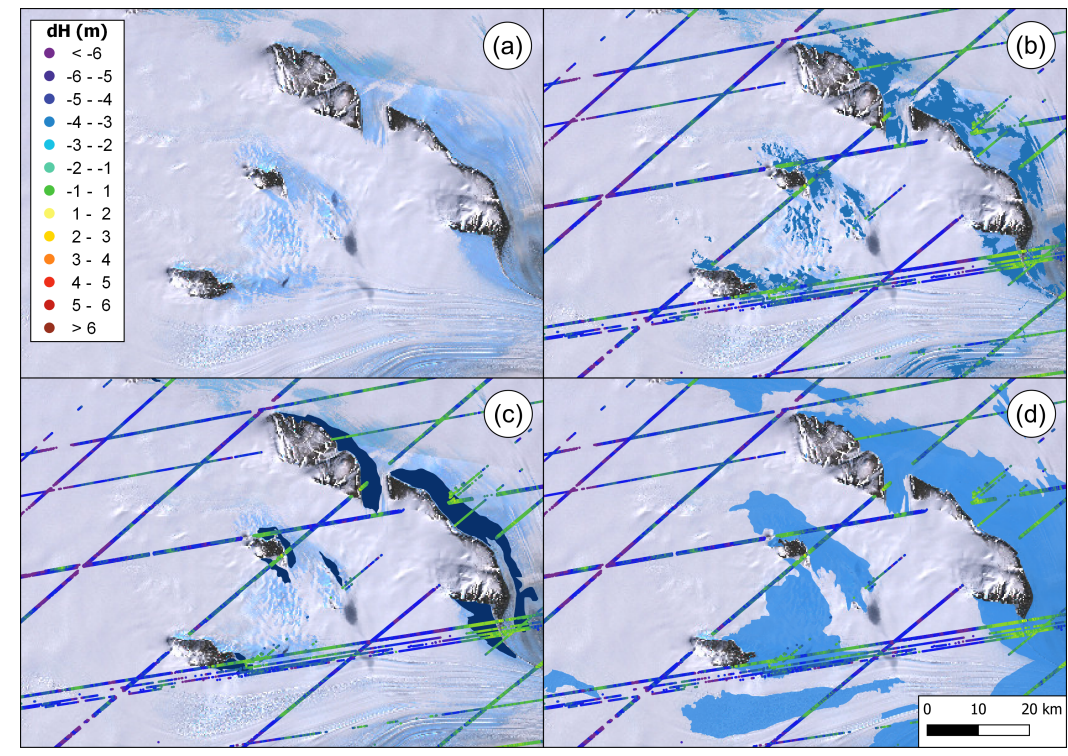

Figure 14. a) Subset of Landsat image used for classification, b) proposed BIA classification, c) AADC BIAs, and d) LC2000 BIAs. b)-d) are overlaid with the height differences TanDEM-X minus ICESat.

Table 2. Accuracy numbers for height differences TanDEM-X minus ICESat for different classifications of Southern Prince Charles Mountains (Fig. 13).

\begin{tabular}{llrrr}
\hline Classification & Class & $\begin{array}{r}\text { Mean } \\
(\mathrm{m})\end{array}$ & $\begin{array}{r}\text { STD } \\
(\mathrm{m})\end{array}$ & \#points \\
\hline AntarcticaLC2000 & BIAs & -1.01 & 1.57 & 43,733 \\
& snow/firn & -3.00 & 1.69 & 121,435 \\
& ice/freerocks & 1.58 & 0.95 & 447 \\
\hline AADC & BIAs & -0.29 & 1.44 & 7,512 \\
& non-BIAs & -2.57 & 1.85 & 158,212 \\
\hline Proposed classif. & BIAs & -0.40 & 1.47 & 7,299 \\
& rocks & 1.93 & 1.32 & 83 \\
& dark snow (SWIR) & -0.47 & 2.01 & 7,279 \\
& dark snow/ice & -0.84 & 1.61 & 1,899 \\
& textured ice & -1.43 & 1.32 & 5,457 \\
& snow & -2.74 & 1.77 & 143,069 \\
\hline
\end{tabular}

that states no significant X-Band penetration into BIAs. From these results, it can be concluded that BIA is very well suited for the absolute height calibration and validation of InSAR DEMs. 
https://doi.org/10.5194/tc-2021-19

Preprint. Discussion started: 15 February 2021

(c) Author(s) 2021. CC BY 4.0 License.

(c) (i)

\subsection{Comparison to IceBridge}

Figure 15 shows the distribution of height differences between TanDEM-X DEM and the IceBridge elevation measurements acquired in October 2014 for two test sites which are located around the South Pole (Fig. 15a) and at the Recovery Glacier in the northwest of the AIS (Fig. 15b).

Table 3. Accuracy numbers for height differences TanDEM-X minus Icebridge for October 2014 campaign.

\begin{tabular}{lrrrrrrrr}
\hline Region & $\begin{array}{r}\text { Mean } \\
(\mathrm{m})\end{array}$ & $\begin{array}{r}\text { Median } \\
(\mathrm{m})\end{array}$ & $\begin{array}{r}\text { STD } \\
(\mathrm{m})\end{array}$ & $\begin{array}{r}\text { RMSE } \\
(\mathrm{m})\end{array}$ & $\begin{array}{r}\text { MAD } \\
(\mathrm{m})\end{array}$ & $\begin{array}{r}\text { NMAD } \\
(\mathrm{m})\end{array}$ & $\begin{array}{r}\text { LE90 } \\
(\mathrm{m})\end{array}$ & \#points \\
\hline South Pole & -4.04 & -4.16 & 1.70 & 4.38 & 0.94 & 1.40 & 6.02 & 160,949 \\
Recovery glacier & -2.06 & -1.79 & 2.46 & 3.20 & 1.08 & 1.60 & 4.69 & 164,439 \\
\hline
\end{tabular}

The corresponding statistical metrics are given in Table 3, and in addition, Fig. 16 shows the spatial distribution of the height differences for the two test sites. The differences between TanDEM-X DEM and IceBridge elevation measurements at the South Pole shown in Fig. 15a are distributed around a mean value of $-4.04 \mathrm{~m}$ with a standard deviation of $1.70 \mathrm{~m}$. The NMAD, which represents a robust estimate for the standard deviation for non-normally distributed height differences (Höhle and Höhle, 2009), is quite small with a value of $1.40 \mathrm{~m}$, while the LE90 is $6.02 \mathrm{~m}$ (Table 3). In contrast, Fig. 15b shows the height difference histogram at Recovery glacier with a lower mean value with $-2.06 \mathrm{~m}$ between TanDEM-X DEM and IceBridge elevation measurements and a higher standard deviation $(2.46 \mathrm{~m})$, but with similar NMAD of $1.60 \mathrm{~m}$. The larger deviation between TanDEM-X and IceBridge elevation at the South Pole is caused by deeper penetration of the SAR signals, which is related to lower backscatter intensity as shown in Fig. 16 (upper right). The higher variance in height differences at Recovery Glacier indicates a higher variability of signal penetration, which is also reflected in the higher variability of backscatter intensity (Fig. 16, lower right). The large number of height differences around zero at Recovery Glacier is due to areas with negligible signal penetration caused by surface scattering, which in turn leads to higher backscatter intensity, as can be seen in Fig. 16.
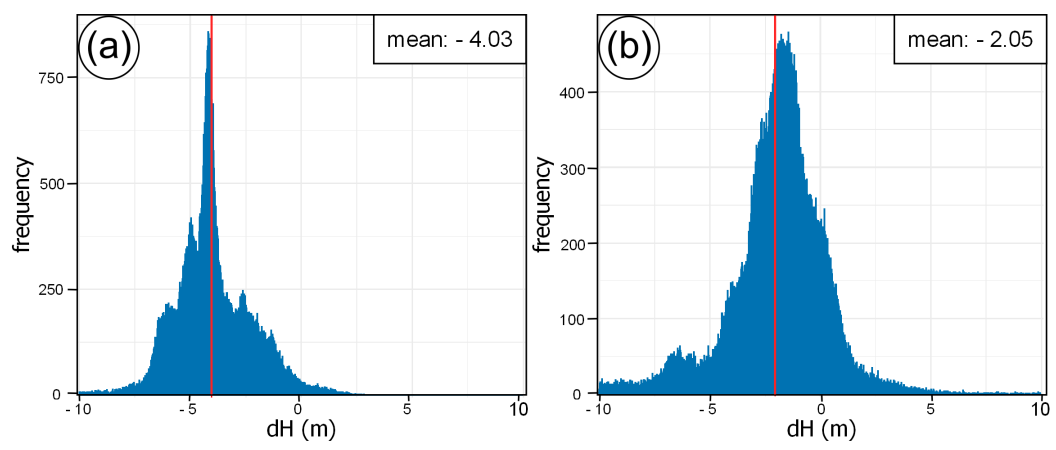

Figure 15. Histogramm of TanDEM-X DEM minus IceBridge ATM differences for October 2014 campaigns a) South Pole and b) Recovery Glacier. 


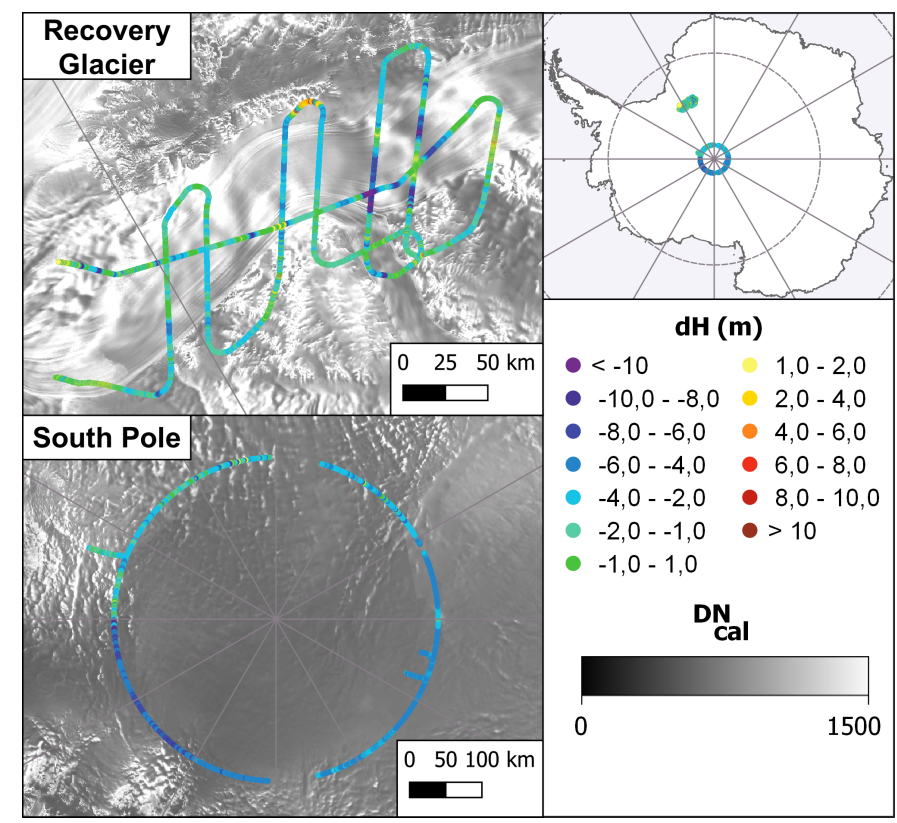

Figure 16. Height differences TanDEM-X DEM minus IceBridge from the October 2014 campaign over the South Pole and the Recovery Glacier displayed over the amplitude mosaic.

In general, best agreement between TanDEM-X DEM and IceBridge elevation measurements can be observed over regions with high backscatter intensity associated with low signal penetration. In contrast, the TanDEM-X DEM can deviate from the IceBridge elevation measurements by up to 10 meters and more in areas with deep signal penetration, which can be identified by low backscatter intensity.

\subsection{Comparison to Cryosat-2 DEM and REMA}

The height differences of the TanDEM-X PolarDEM 90m to the CryoSAT DEM of Slater et al. (2018) and the REMA DEM (Howat et al., 2018) were calculated and the accuracy measures are given in Table 4. For TanDEM-X minus CryoSAT we observe a high negative mean value of $-11.59 \mathrm{~m}$ with high standard deviation $(70.58 \mathrm{~m})$ and RMSE $(71.53 \mathrm{~m})$ values. These values are in strong contrast to the more robust median $(-4.52 \mathrm{~m})$ and NMAD $(3.49 \mathrm{~m})$ and suggest a large amount of high outliers. These are particularly located in mountainous areas where CryoSAT systematically underestimates the elevation. Therefore, strict outlier detection was performed by clipping the height differences above mean $+/-2$ times standard deviation. This improves the measures and results in a mean value of $-5.26 \mathrm{~m}$ with a standard deviation of $15.21 \mathrm{~m}$.

Figure 17 shows the color-coded height differences where the clipped outlier values are marked in white. These areas can be found particularly in mountains where TanDEM-X InSAR and CryoSAT-2 altimeter measurements diverge by up to several hundred meters. In contrast, the differences on the ice sheet show a high agreement, apart from the SAR signal penetration of TanDEM-X, usually between -4 to $-10 \mathrm{~m}$ in the interior of Antarctica. These penetration patterns correspond to the ones 
https://doi.org/10.5194/tc-2021-19

Preprint. Discussion started: 15 February 2021

(c) Author(s) 2021. CC BY 4.0 License.

observed by ICESat (Fig. 11), where the highest penetration-related differences are also in central Antarctica and between $0^{\circ}$ and $30^{\circ}$ East. A sector in West Antarctica (between $90^{\circ}$ and $150^{\circ}$ West) also shows higher differences between TanDEM-X and CryoSAT of up to $-10 \mathrm{~m}$. However, the shape of this higher difference zone seems to be related to the processing windows of CryoSAT. The interior of the CryoSAT DEM was processed by radar altimetry by low-resolution mode (LRM), a pulselimited altimetry with a $2.25 \mathrm{~km}^{2}$ footprint. The ice sheet margins were processed by the higher-resolution SARIn mode, where CryoSat operates as a SAR altimeter. These areas near the coasts generally coincidence well with the TanDEM-X heights. On the one hand, the TanDEM-X DEM elevations in this area are less affected by a penetration bias. On the other hand, CryoSAT seems to also have a penetration bias: the mode mask boundary between CryoSat-2 LRM and SARIn processing modes is obviously visible (Figure 17).

Table 4. Accuracy numbers for height differences TanDEM-X minus Cryosat-2 DEM (Slater et al., 2018) and REMA (Howat et al., 2019).

\begin{tabular}{lrrrrrrr}
\hline DEM difference & $\begin{array}{r}\text { Mean } \\
(\mathrm{m})\end{array}$ & $\begin{array}{r}\text { Median } \\
(\mathrm{m})\end{array}$ & $\begin{array}{r}\text { STD } \\
(\mathrm{m})\end{array}$ & $\begin{array}{r}\text { RMSE } \\
(\mathrm{m})\end{array}$ & $\begin{array}{r}\text { MAD } \\
(\mathrm{m})\end{array}$ & $\begin{array}{r}\text { NMAD } \\
(\mathrm{m})\end{array}$ & $\begin{array}{r}\text { LE90 } \\
(\mathrm{m})\end{array}$ \\
\hline TDM-CS2 & -11.59 & -4.52 & 70.58 & 71.53 & 2.53 & 3.49 & 14.85 \\
TDM-CS2 w/o outlier & -5.26 & -4.45 & 15.21 & 14.10 & 2.28 & 3.38 & 12.29 \\
TDM-REMA & -3.70 & -4.00 & 10.60 & 11.23 & 1.70 & 2.52 & 6.96 \\
\hline
\end{tabular}

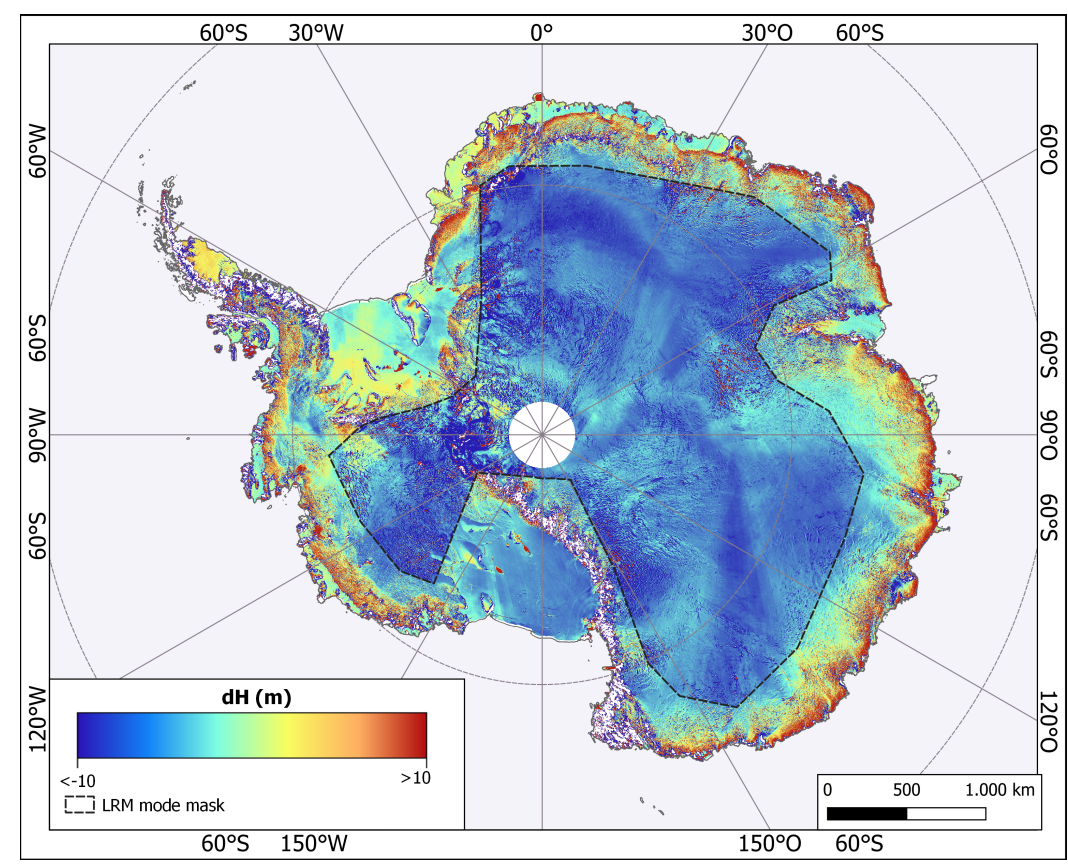

Figure 17. Height difference between TanDEM-X DEM minus CryoSat-2 DEM (rocks: mean +/-2*STD is masked out in white). 
The accuracy measures TanDEM-X minus REMA correspond more consistently (Table 4) and are not that outlier prone with similar mean $(-3.70 \mathrm{~m})$ and median $(4.00 \mathrm{~m})$ values as well as a lower standard deviation $(10.60 \mathrm{~m})$ and NMAD $(2.52 \mathrm{~m})$. The color-coded height differences in Fig. 18 show an overall good agreement, especially near the coast, as the InSAR scattering center in percolated areas lies near the surface. The InSAR signal penetration of TanDEM-X into the ice sheet in the inner Antarctic part is clearly visible. The same elevated area in west Antarctica could be observed similarly to ICESat where presumably a DEM calibration error for TanDEM-X occurred as we observed disparities between two DEM calibration blocks of up to $4 \mathrm{~m}$ in this area. Note that this comparison refers to $1 \mathrm{~km}$ versions of TanDEM-X DEM and REMA. Regarding the coverage, there are slight differences since REMA does not cover the Pole and the islands north of Ross ice shelf. The most prominent feature regarding the coverage is that REMA has some local gaps and missing stripes most obvious near the Pole. These areas are marked in white in Fig. 18. In contrast to REMA, the TanDEM-X PolarDEM 90m has an almost complete coverage.

However, some erroneous TanDEM-X DEM scenes can be detected. These are rectangular areas with the size of a DEM scene (approx. $30 \mathrm{~km} \times 55 \mathrm{~km}$ ) that show a constant height offset in the order of a multiple of half the height of ambiguity (such as the red spot in the western AIS in Fig. 18). These so-called PI-jump errors (Rizzoli et al., 2017; Dong et al., 2020) could not be detected fully like for almost the rest of the globe due to the lack of adequate reference data. On the other hand, especially in east Antarctica, some rectangular offset area divergences are visible, e.g. blue quadratic areas near the Pole, that might suggest a processing error in REMA as TanDEM-X was processed in geographic coordinates.

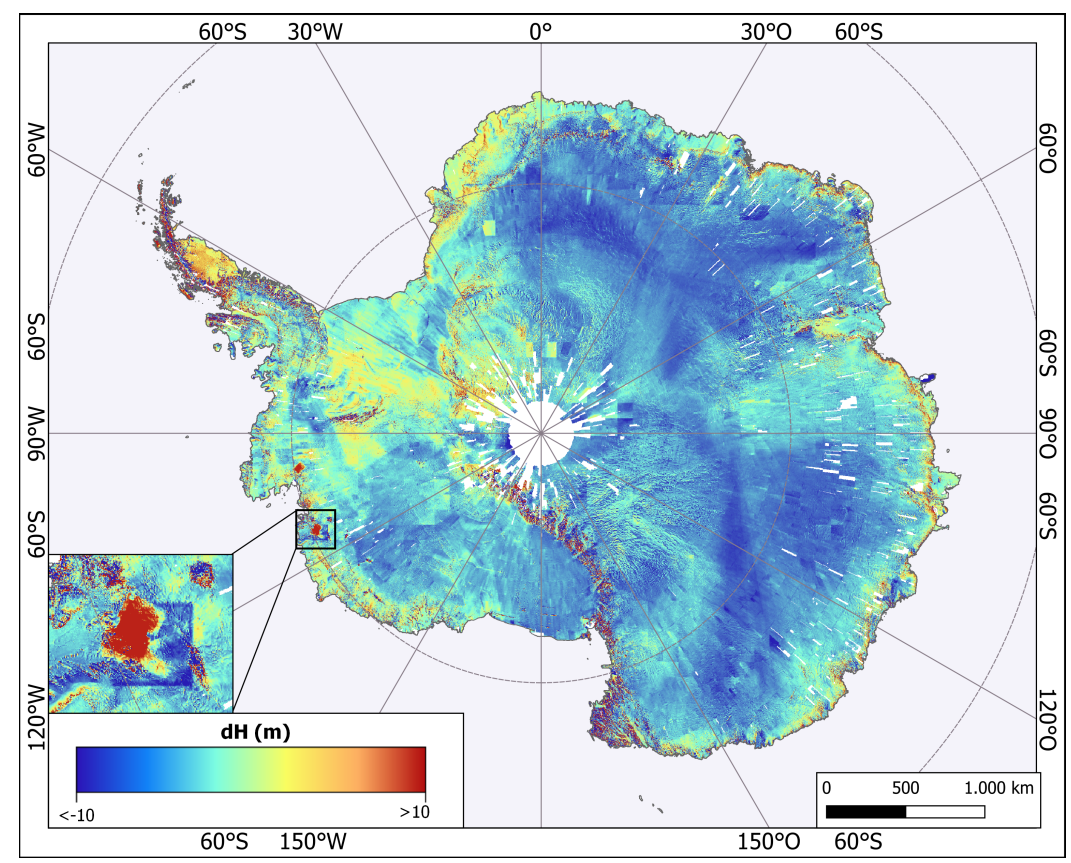

Figure 18. Height difference between TanDEM-X DEM minus REMA. 
https://doi.org/10.5194/tc-2021-19

Preprint. Discussion started: 15 February 2021

(c) Author(s) 2021. CC BY 4.0 License.

\section{(c) (i)}

Some consistent areas clearly stand out, like the Pine and Thwaites glaciers, where we have a quite good correspondence in height for this dynamic area. On the one hand, this is due to the close acquisition time of both data and on the other hand, the flowing part of the ice shelf corresponds well where no penetration is given. In summary, due to the high vertical resolution and coverage, so far undetected errors in TanDEM-X PolarDEM could be revealed by REMA. Cryosat-2 DEM and REMA are both highly accurate and therefore allow an error characterization of the data set.

\section{Conclusions and outlook}

The TanDEM-X PolarDEM of Antarctica is a new interferometric DEM data set freely available to scientific users in $90 \mathrm{~m}$ horizontal spacing. It is void-free, only the elevations of a few islands are missing on the Antarctic Peninsula. A new DEM calibration approach, additional acquisitions and new editing techniques were utilized to shape the global TanDEM-X DEM into the new TanDEM-X PolarDEM 90m product. In addition, the interferometric DEM was validated with blue ice areas that seem to be free of penetration effects. The corresponding accuracy measures are close to the absolute accuracy measures found by validation with highly accurate GPS tracks on other continents (Wessel et al., 2018). The quality of the data in terms of absolute vertical accuracy, evaluated by comparing the TanDEM-X DEM to ICESat heights, delivered a brilliant performance with a median value of $-0.32 \mathrm{~m}$ and an absolute height accuracy at $90 \%$ confidence level of $3.74 \mathrm{~m}$ on blue-ice regions. Even including rock and snow/firn areas, which are characterized by radar wave penetration phenomena, the overall absolute vertical accuracy at $90 \%$ confidence level was just $6.25 \mathrm{~m}$. The conducted DEM calibration was designed to preserve the SAR signal penetration into the ice sheet. A further refinement of this data set might be possible by correcting the penetration bias, as shown shown e.g. by Abdullahi et al. (2019) on the base of coherence and amplitude, which would improve the comparability with other data. An adequate handling of individual height offset scenes like in Dong et al. (2020) and a recalibration near the Antarctic Peninsula could lead to a further improvement of this data set. All in all, TanDEM-X PolarDEM is a framework for the provision of derivatives of the global digital elevation model of the TanDEM-X mission which resolved some limitations, including edited DEM products; single year coverages and penetration bias corrected DEMs of Polar Regions will be supplemented in the future, especially over Greenland. Together with the excellent global absolute accuracy this edited TanDEM-X PolarDEM 90m product for Antarctica provides a high level of detail. It serves as a new topographic reference from which the monitoring of the dynamic topographic changes in Antarctica will benefit.

Data availability. The presented TanDEM-X PolarDEM 90m for Antarctica in Polar Stereographic projection is made freely available to scientific users via DLR's Earth Observation Center GeoPortal (https://geoservice.dlr.de/web/maps). The TanDEM-X derived coastline will follow after its release. The data sets from NASA's ICESat and IceBridge operations are provided by the National Snow and Ice Data Center (NSIDC), Distributed Active Archive Center, Boulder, CO, USA at https://nsidc.org (Studinger, 2014, updated 2020) and the coastline of the Antarctic digital database by SCAR (https://www.add.scar.org). REMA mosaic was provided by the Byrd Polar and Climate Research Center and the U.S. Polar Geospatial Center at https://www.pgc.umn.edu/dta/rema/ (Howat et al., 2019). The CryoSat-2 DEM was made available via the Centre for Polar Observation and Modelling data portal (http://www.cpom.ucl.ac.uk/csopr/) and the Antarctica classifications by Hui et al. (2017b) (AntarcticaLC2000) and from the Australian AntarcticData Centre (AADC) (Bender and Smith, 2013, updated 2017). 
https://doi.org/10.5194/tc-2021-19

Preprint. Discussion started: 15 February 2021

(c) Author(s) 2021. CC BY 4.0 License.

(c) (i)

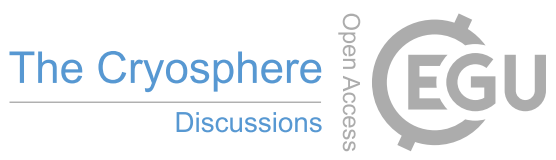

\section{Acknowledgment}

The TanDEM-X mission was led by the German Aerospace Center (DLR). We acknowledge the whole Ground Segment team for their outstanding work which builds the foundation of this new data set. In particular, we would like to thank Gerhard Krieger for the discussions on the InSAR DEM calibration and Markus Breunig for conducting the operational TanDEM-X DEM generation.

\section{Appendix A: Product description}

The global DEM delivered by TanDEM-X has been defined in the TanDEM-X DEM product specification document (Wessel, 2018). In contrast to this, the gap-filled and edited TanDEM-X PolarDEM 90m of Antarctica introduced in this paper is described by the following parameters (Huber, 2020):

- Projection: WGS 84 / Antarctic Polar Stereographic

- EPSG: 3031

- Vertical datum: WGS-84G1150 (ITRF2008 and ITRF2010)

- Height reference: ellipsoidal heights

- Elevation unit: meters

- Grid spacing: $90 \mathrm{~m}$

- Coverage: all land masses below $60^{\circ}$ South in 4 tiles

- Acquisition dates: mainly April 2013 to Oct. 2014 (for gap filling July 2016 to September 2017)

- Data format: 32 bit signed float

- No data value: -32767.0

- License: TanDEM-X PolarDEM 90m for Antarctica is licensed for scientific use

Author contributions. The study was conceived and led by BW, MH and AR. The developments were conducted in case of DEM block adjustment by AG, BW and AB, DEM mosaicking by AG, MH and AB, gap filling by $\mathrm{CW}$ and $\mathrm{MH}$ and DEM editing by MH, FR and NO.

The data analysis and validation were undertaken by MH, BW, IG, SA, UM and CW. Original draft preparation of the paper was conducted by BW, MH, SA, IG, UM, CW, FR and AR. All authors reviewed and edited the paper.

Competing interests. The authors declare that they have no conflict of interest. 
https://doi.org/10.5194/tc-2021-19

Preprint. Discussion started: 15 February 2021

(c) Author(s) 2021. CC BY 4.0 License.

(c) (P)

\section{References}

Abdullahi, S., Wessel, B., Huber, M., Wendleder, A., Roth, A., and Künzer, C.: Estimating penetration-related X-band InSAR elevation bias

- A study over the Greenland ice sheet, Remote Sensing, 11, 1-19, https://doi.org/10.3390/rs11242903, 2019.

Bender, A. and Smith, D.: Areas of exposed rock and blue ice in the Australian Antarctic Territory digitised from satellite images. Australian Antarctic Data Centre - CAASM Metadata, available at: https://data.aad.gov.au/metadata/records/gis310 (last access: 29 June 2020), 2013, updated 2017.

Bintanja, R.: On the glaciological, meteorological, and climatological significance of Antarctic blue ice areas, Rev. Geophys., 37, 337-359, https://doi.org/10.1029/1999RG900007, 1999.

Borla Tridon, D., Bachmann, M., Schulze, D., Ortega-Miguez, C., M. D. P., Martone, M., Böer, J., and Zink, M.: TanDEM-X: DEM Acquisition in the Third Year, International Journal of Space Science and Engineering, 1, 367-381, https://doi.org/10.1504/IJSPACESE.2013.059270, 2013.

Brenner, A. C., DiMarzio, J. P., and Zwally, H. J.: Precision and Accuracy of Satellite Radar and Laser Altimeter Data Over the Continental Ice Sheets, IEEE T. Geosci. Remote, 45, 321-331, https://doi.org/10.1109/TGRS.2006.887172, 2007.

Dehecq, A., Millan, R., Berthier, E., Gourmelen, N., Trouvé, E., and Vionnet, V.: Elevation Changes Inferred From TanDEM-X Data Over the Mont-Blanc Area: Impact of the X-Band Interferometric Bias, IEEE J. Sel. Topics Appl. Earth Observ. Remote Sens., 9, 3870-3882, https://doi.org/10.1109/JSTARS.2016.2581482, 2016.

Dong, Y., Zhao, J., Floricioiu, D., Krieger, L., Fritz, T., and Eineder, M.: High-resolution topography of the Antarctic Peninsula combining

TanDEM-X DEM and REMA mosaic, The Cryosphere Discussions, 2020, 1-27, https://doi.org/10.5194/tc-2020-323, 2020.

EGM2008 Development Team: EGM2008 - WGS 84 Version, available at: https://earth-info.nga.mil/GandG/ wgs84/gravitymod/egm2008/egm08_wgs84.html (last access: 27 April 2020), 2012.

Fischer, G., Papathanassiou, K. P., and Hajnsek, I.: Modeling and Compensation of the Penetration Bias in InSAR DEMs of Ice Sheets at Different Frequencies, IEEE J. Sel. Topics Appl. Earth Observ. Remote Sens., 13, 2698-2707, https://doi.org/10.1109/JSTARS.2020.2992530, 2020.

Forsberg, R., Sørensen, L., and Simonsen, S.: Greenland and Antarctica Ice Sheet Mass Changes and Effects on Global Sea Level, in: Integrative Study of the Mean Sea Level and Its Components, edited by Cazenave, A., Champollion, N., Paul, F., and Benveniste, J., pp. 91-106, Springer International Publishing, Cham, https://doi.org/10.1007/978-3-319-56490-6_5, 2017.

Fretwell, P., Pritchard, H. D., Vaughan, D. G., Bamber, J. L., Barrand, N. E., Bell, R., Bianchi, C., Bingham, R. G., Blankenship, D. D., Casassa, G., Catania, G., Callens, D., Conway, H., Cook, A. J., Corr, H. F. J., Damaske, D., Damm, V., Ferraccioli, F., Forsberg, R., Fujita, S., Gim, Y., Gogineni, P., Griggs, J. A., Hindmarsh, R. C. A., Holmlund, P., Holt, J. W., Jacobel, R. W., Jenkins, A., Jokat, W., Jordan, T., King, E. C., Kohler, J., Krabill, W., Riger-Kusk, M., Langley, K. A., Leitchenkov, G., Leuschen, C., Luyendyk, B. P., Matsuoka, K., Mouginot, J., Nitsche, F. O., Nogi, Y., Nost, O. A., Popov, S. V., Rignot, E., Rippin, D. M., Rivera, A., Roberts, J., Ross, N., Siegert, M. J., Smith, A. M., Steinhage, D., Studinger, M., Sun, B., Tinto, B. K., Welch, B. C., Wilson, D., Young, D. A., Xiangbin, C., and Zirizzotti, A.: Bedmap2: improved ice bed, surface and thickness datasets for Antarctica, The Cryosphere, 7, 375-393, https://doi.org/10.5194/tc-7375-2013, 2013.

Fritz, T., Rossi, C., Yague-Martinez, N., Rodriguez-Gonzalez, F., Lachaise, M., and Breit, H.: Interferometric Processing of TanDEM-X Data, in: Proceesings of IEEE International Geoscience and Remote Sensing Symposium, 24 - 29 July 2011, Vancouver, British Columbia, Canada, pp. 2428-2431, 2011. 
https://doi.org/10.5194/tc-2021-19

Preprint. Discussion started: 15 February 2021

(c) Author(s) 2021. CC BY 4.0 License.

(c) (i)

515 Giovinetto, M. B.: Distribution of diagenetic snow facies in Antarctica and in Greenland, Arctic, 17, 32-40, 1964.

Gruber, A., Wessel, B., Huber, M., and Roth, A.: Operational TanDEM-X DEM calibration and first validation results, ISPRS J. Photogramm. Remote Sens., 73, 39-49, https://doi.org/10.1016/j.isprsjprs.2012.06.002, 2012.

Gruber, A., Wessel, B., Martone, M., and Roth, A.: The TanDEM-X DEM Mosaicking: Fusion of Multiple Acquisitions Using InSAR Quality Parameters., ISPRS J. Photogramm. Remote Sens., 9, 1047-1057, https://doi.org/10.1109/JSTARS.2015.2421879, 2016.

Harding, D. J. and Carabajal, C. C.: ICESat waveform measurements of within-footprint topographic relief and vegetation vertical structure, Geophys. Res. Lett., 32, https://doi.org/10.1029/2005GL023471, 2005.

Helm, V., Humbert, A., and Miller, H.: Elevation and elevation change of Greenland and Antarctica derived from CryoSat-2, The Cryosphere, 8, 1539-1559, https://doi.org/10.5194/tc-8-1539-2014, 2014.

Howat, I., Morin, P., Porter, C., and Noh, M.-J.: The Reference Elevation Model of Antarctica, https://doi.org/10.7910/DVN/SAIK8B, last access: 29 June 2020, 2018.

Howat, I. M., Porter, C., Smith, B. E., Noh, M.-J., and Morin, P.: The Reference Elevation Model of Antarctica, The Cryosphere, 13, 665-674, https://doi.org/10.5194/tc-13-665-2019, 2019.

Huber, M.: TanDEM-X PolarDEM Product Description, DLR, available at: https://geoservice.dlr.de/resources/pdf/polardem90/ TD-GS-PS0208_PolarDEM-Product-Description.pdf, last access: 29 December 2020, Technical Note 1.4, German Aerospace Center, 2020.

Huber, M., Wessel, B., Kosmann, D., Felbier, A., Schwieger, V., Habermeyer, M., Wendleder, A., and Roth, A.: Ensuring globally the TanDEM-X height accuracy: Analysis of the reference data sets ICESat, SRTM and KGPS-tracks, in: Proceesings of IEEE International Geoscience and Remote Sensing Symposium, 12-17 July 2009, Cape Town, South Africa, pp. II-769-II-772, 2009.

Huber, M., Gruber, A., Wessel, B., Breunig, M., and Wendleder, A.: Validation of the tie-point concepts by the DEM adjustment approach of TanDEM-X, in: Proceedings of IEEE International Geoscience and Remote Sensing Symposium, 25-30 July 2010, Honolulu, USA, pp. 2644-2647, 2010.

Huber, M., Wessel, B., Wendleder, A., Hoffmann, J., and Roth, A.: A framework for an automatical editing of TanDEM-X digital elevation models, in: Proceesings of IEEE International Geoscience and Remote Sensing Symposium, 26-31 July 2015, Milan, Italy, pp. 3826-3829, 2015.

Hueso Gonzalez, J., Bachmann, M., Scheiber, R., and Krieger, G.: Definition of ICESat Selection Criteria for their Use as Height References for TanDEM-X, IEEE T. Geosci. Remote, 48, 2750-2757, https://doi.org/10.1109/TGRS.2010.2041355, 2010.

Hui, F., Kang, J., Liu, Y., Cheng, X., Gong, P., Wang, F., Li, Z., Ye, Y., and Guo, Z.: AntarcticaLC2000: The new Antarctic land cover database for the year 2000, Science China Earth Sciences, 60, 686-696, https://doi.org/10.1007/s11430-016-0029-2, 2017a.

Hui, F., Kang, J., Liu, Y., Cheng, X., Gong, P., Wang, F., Li, Z., Ye, Y., and Guo, Z.: AntarcticaLC2000: The new Antarctic land cover database for the year 2000, https://doi.org/10.5281/zenodo.826032, 2017b.

545 Höhle, J. and Höhle, M.: Accuracy assessment of digital elevation models by means of robust statistical methods, ISPRS J. Photogramm. Remote Sens., 64, 398-406, https://doi.org/https://doi.org/10.1016/j.isprsjprs.2009.02.003, 2009.

Jezek, K. C.: RADARSAT-1 Antarctic mapping project: Change detection and surface velocity campaign, Ann. Glaciol., 34, 263-268, https://doi.org/10.3189/172756402781818030, 2002.

Koenig, L., Martin, S., Studinger, M., and Sonntag, J.: Polar Airborne Observations Fill Gap in Satellite Data, Eos, Transactions American Geophysical Union, 91, 333-334, https://doi.org/10.1029/2010EO380002, 2010. 
https://doi.org/10.5194/tc-2021-19

Preprint. Discussion started: 15 February 2021

(c) Author(s) 2021. CC BY 4.0 License.

(c) (i)

Krabill, W., Abdalati, W., Frederick, E., Manizade, S., Martin, C., Sonntag, J., Swift, R., Thomas, R., and Yungel, J.: Aircraft laser altimetry measurement of elevation changes of the greenland ice sheet: technique and accuracy assessment, J. Geodyn., 34, 357-376, https://doi.org/https://doi.org/10.1016/S0264-3707(02)00040-6, 2002.

Krieger, G., Moreira, A., Fiedler, H., Hajnsek, I., Werner, M., Younis, M., and Zink, M.: TanDEM-X : A Satellite Formation for High Resolution SAR Interferometry, IEEE T. Geosci. Remote, 45, 3317-3341, https://doi.org/10.1109/TGRS.2007.900693, 2007.

Lachaise, M., Fritz, T., and Bamler, R.: The Dual-Baseline Phase Unwrapping Correction framework for the TanDEM-X Mission Part 1: Theoretical description and algorithms, IEEE T. Geosci. Remote, 56, 780-798, https://doi.org/10.1109/TGRS.2017.2754923, 2018.

Macelloni, G., Leduc-Leballeur, M., Montomoli, F., Brogioni, M., Ritz, C., and Picard, G.: On the retrieval of internal temperature of Antarctica Ice Sheet by using SMOS observations, Remote Sens. Environ., 233, https://doi.org/10.1016/j.rse.2019.111405, 2019.

Mengel, M., Nauels, A., Rogelj, J., and Schleussner, C.-F.: Committed sea-level rise under the Paris Agreement and the legacy of delayed mitigation action, Nat. Commun., 9, 601, https://doi.org/10.1038/s41467-018-02985-8, 2018.

Orheim, O. and Lucchitta, B.: Investigating climate change by digital analysis of blue ice extent on satellite images of Antarctica, Ann. Glaciol., 14, 211-215, https://doi.org/10.1017/S0260305500008600, 1990.

Rizzoli, P., Martone, M., Gonzalez, C., Wecklich, C., Borla Tridon, D., Bräutigam, B., Bachmann, M., Schulze, D., Fritz, T., Huber, M., Wessel, B., Krieger, G., Zink, M., and Moreira, A.: Generation and performance assessment of the global TanDEM-X digital elevation model, ISPRS J. Photogramm. Remote Sens., 132, 119-139, https://doi.org/10.1016/j.isprsjprs.2017.08.008, 2017.

Rossi, C., Rodriguez Gonzalez, F., Fritz, T., Yague-Martinez, N., and Eineder, M.: TanDEM-X calibrated Raw DEM generatiion, ISPRS J. Photogramm. Remote Sens., 73, 12-20, https://doi.org/10.1016/j.isprsjprs.2012.05.014, 2012.

Rott, H., Wuite, J., Nagler, T., Floricioiu, D., Rizzoli, P., and Helm, V.: InSAR Scattering Phase Centre of Antarctic Snow - An Experimental Study, in: Proceedings of Fringe - 10th International Workshop on Advances in the Science and Applications of SAR Interferometry and Sentinel-1 InSAR, 5.-9. Jun. 2017, Helsinki, Finnland, 2017.

Rott, H., Scheiblauer, S., Wuite, J., Krieger, L., Floricioiu, D., Rizzoli, P., Libert, L., and Nagler, T.: Penetration of interferometric radar signals in Antarctic snow, The Cryosphere Discussions, 2021, 1-27, https://doi.org/10.5194/tc-2020-380, 2021.

Scambos, T. A., Campbell, G. G., Pope, A., Haran, T., Muto, A., Lazzara, M., Reijmer, C. H., and van den Broeke, M. R.: Ultralow Surface Temperatures in East Antarctica From Satellite Thermal Infrared Mapping: The Coldest Places on Earth, Geophys. Res. Lett., 45, 61246133, https://doi.org/https://doi.org/10.1029/2018GL078133, 2018.

Schutz, B., Zwally, H., Shuman, C., Hancock, D., and Di Marzio, J.: Overview of the ICESat Mission, Geophys. Res. Lett., $32,2005$.

Scientific Committee on Antarctic Research: Coastline medium res polygon v7.1, available at: https://www.add.scar.org/ (last access: 29 June 2020), 2019.

Shepherd, A., Ivins, E., Rignot, E., Smith, B., van den Broeke, M., Velicogna, I., Whitehouse, P., Briggs, K., Joughin, I., Krinner, G., Nowicki, S., Payne, T., Scambos, T., Schlegel, N., Geruo, A., Agosta, C., Ahlstrøm, A., Babonis, G., Barletta, V., Blazquez, A., Bonin, J., Csatho, B., Cullather, R., Felikson, D., Fettweis, X., Forsberg, R., Gallee, H., Gardner, A., Gilbert, L., Groh, A., Gunter, B., Hanna, E., Harig, C., Helm, V., Horvath, A., Horwath, M., Khan, S., Kjeldsen, K. K., Konrad, H., Langen, P., Lecavalier, B., Loomis, B., Luthcke, S., McMillan, M., Melini, D., Mernild, S., Mohajerani, Y., Moore, P., Mouginot, J., Moyano, G., Muir, A., Nagler, T., Nield, G., Nilsson, J., Noel, B., Otosaka, I., Pattle, M. E., Peltier, W. R., Pie, N., Rietbroek, R., Rott, H., Sandberg-Sørensen, L., Sasgen, I., Save, H., Scheuchl, B., Schrama, E., Schröder, L., Seo, K.-W., Simonsen, S., Slater, T., Spada, G., Sutterley, T., Talpe, M., Tarasov, L., van de Berg, W. J., van der Wal, W., van Wessem, M., Vishwakarma, B. D., Wiese, D., Wouters, B., and team, T. I. M. B. I. E.: Mass balance of the Antarctic Ice Sheet from 1992 to 2017, Nature, 558, 219-222, https://doi.org/10.1038/s41586-018-0179-y, 2018. 
https://doi.org/10.5194/tc-2021-19

Preprint. Discussion started: 15 February 2021

(c) Author(s) 2021. CC BY 4.0 License.

(c) (1)

Slater, T., Shepherd, A., McMillan, M., Muir, A., Gilbert, L., Hogg, A. E., Konrad, H., and Parrinello, T.: A new digital elevation model of Antarctica derived from CryoSat-2 altimetry, The Cryosphere, 12, 1551-1562, https://doi.org/10.5194/tc-12-1551-2018, 2018.

Studinger, M.: IceBridge ATM L2 Icessn Elevation, Slope, and Roughness, Version 2, available at: https://doi.org/10.5067/CPRXXK3F39RV (last access: 29 June 2020), 2014, updated 2020.

Sutterley, T. C., Velicogna, I., Rignot, E., Mouginot, J., Flament, T., van den Broeke, M. R., van Wessem, J. M., and Reijmer, C. H.: Mass loss of the Amundsen Sea Embayment of West Antarctica from four independent techniques, Geophys. Res. Lett., 41, 8421-8428, https://doi.org/10.1002/2014GL061940, 2014.

Ulaby, F. T., Moore, R. K., and Fung, A. K.: Microwave remote sensing, active and passive, Addison-Wesley, Reading, MA, 1986.

USGS: Landsat Image Mosaic Of Antarctica (LIMA), last access: 11 January 2021, https://lima.usgs.gov/, 2008.

Wessel, B.: TanDEM-X Ground Segment - DEM Products Specification Document, Technical Note, DLR 3.2, German Aerospace Center, last access: 11 January 2021, 2018.

Wessel, B., Bertram, A., Gruber, A., Bemm, S., and Dech, S.: A new high-resolution elevation model of Greenland derived from TanDEM-X, in: ISPRS Ann. Photogramm. Remote Sens. Spatial Inf. Sci., pp. 9-16, 2016.

Wessel, B., Huber, M., Wohlfart, C., Marschalk, U., Kosmann, D., and Roth, A.: Accuracy Assessment of the Global TanDEM-X Digital Elevation Model with GPS Data, ISPRS J. Photogramm. Remote Sens., 139, 171-182, https://doi.org/10.1016/j.isprsjprs.2018.02.017, 2018.

605 Winther, J.-G., Jespersen, M. N., and Liston, G. E.: Blue-ice areas in Antarctica derived from NOAA AVHRR satellite data, J. Glaciol., 47, 325-334, https://doi.org/10.3189/172756501781832386, 2001.

Zhao, J. and Floricioiu, D.: The penetration effects on TanDEM-X elevation using the GNSS and laser altimetry measurements in Antarctica, in: Proceedings of the Int. Archives of Photogramm., Remote Sens. and Spatial Inf. Sci., ISPRS Geospatial Week 2017, 18-22 September 2017, Wuhan, China., vol. XLII-2 (W7), pp. 1593-1600, https://doi.org/10.5194/isprs-archives-XLII-2-W7-1593-2017, 2017.

610 Zwally, H. J., R., Schutz, C., Bentley, J., Bufton, T., Herring, J., Minster, J., and Spinhirne, R. T.: GLAS/ICESat L2 Global Land Surface Altimetry Data, Version 31, GLA14, https://doi.org/10.5067/ICESAT/GLAS/DATA227 (last access: 29 June 2020), 2012. 